\title{
The Role of "Mixed" Orexigenic and Anorexigenic Signals and Autoantibodies Reacting with Appetite-Regulating Neuropeptides and Peptides of the Adipose Tissue-Gut-Brain Axis: Relevance to Food Intake and Nutritional Status in Patients with Anorexia Nervosa and Bulimia Nervosa
}

\author{
Kvido Smitka, ${ }^{1}$ Hana Papezova, ${ }^{2}$ Karel Vondra, ${ }^{1}$ Martin Hill, ${ }^{1}$ \\ Vojtech Hainer, ${ }^{1}$ and Jara Nedvidkova ${ }^{1}$ \\ ${ }^{1}$ Institute of Endocrinology, Laboratory of Clinical and Experimental Neuroendocrinology, Narodni 8, 11694 Prague 1, Czech Republic \\ ${ }^{2}$ Psychiatric Clinic, First Faculty of Medicine, Charles University, Ke Karlovu 11, 12108 Prague 2, Czech Republic \\ Correspondence should be addressed to Jara Nedvidkova; jnedvidkova@endo.cz
}

Received 28 March 2013; Accepted 11 July 2013

Academic Editor: Carlos Dieguez

Copyright (C) 2013 Kvido Smitka et al. This is an open access article distributed under the Creative Commons Attribution License, which permits unrestricted use, distribution, and reproduction in any medium, provided the original work is properly cited.

Eating disorders such as anorexia (AN) and bulimia nervosa $(\mathrm{BN})$ are characterized by abnormal eating behavior. The essential aspect of $\mathrm{AN}$ is that the individual refuses to maintain a minimal normal body weight. The main features of BN are binge eating and inappropriate compensatory methods to prevent weight gain. The gut-brain-adipose tissue (AT) peptides and neutralizing autoantibodies play an important role in the regulation of eating behavior and growth hormone release. The mechanisms for controlling food intake involve an interplay between gut, brain, and AT. Parasympathetic, sympathetic, and serotoninergic systems are required for communication between brain satiety centre, gut, and AT. These neuronal circuits include neuropeptides ghrelin, neuropeptide Y (NPY), peptide YY (PYY), cholecystokinin (CCK), leptin, putative anorexigen obestatin, monoamines dopamine, norepinephrine (NE), serotonin, and neutralizing autoantibodies. This extensive and detailed report reviews data that demonstrate that hunger-satiety signals play an important role in the pathogenesis of eating disorders. Neuroendocrine dysregulations of the ATgut-brain axis peptides and neutralizing autoantibodies may result in $\mathrm{AN}$ and BN. The circulating autoantibodies can be purified and used as pharmacological tools in AN and BN. Further research is required to investigate the orexigenic/anorexigenic synthetic analogs and monoclonal antibodies for potential treatment of eating disorders in clinical practice.

\section{Introduction}

Anorexia nervosa (AN) and bulimia nervosa (BN) are eating disorders characterized by loss of self-control in eating behavior and disturbed emotions including high anxiety. These disorders affect 2-3\% of young women [1]. AN is a serious eating disorder with the highest mortality rate among other psychiatric disorders $[2,3]$. AN is characterized by chronic selfstarvation, amenorrhea, and severe weight loss due to reduction of both fat mass and fat-free mass mainly at the expense of adipose tissue (AT). $\mathrm{BN}$ is an eating disorder in which the subject engages in recurrent binge eating. To compensate for the intake of the food and prevent weight gain, this is followed by induction of vomiting, use of laxatives, enemas, diuretics, excessive exercising, or fasting; this results in dysregulation of endogenous endocrine axes. In $\mathrm{BN}$, the phenomenon of binge eating, that is, consumption of large amounts of food in a short time period, is accompanied by a sensation of losing control over eating [4].

The gastrointestinal tract, central nervous system, and AT referred to as the AT-gut-brain axis produce a series of hormones with orexigenic and anorexigenic effects [5-14] (Figure 1). On the one hand, ghrelin could represent a regulatory circuit controlling appetite and energy homeostasis by stimulating the release of other orexigenic peptides and neurotransmitters as well as neuropeptide Y (NPY) [15]. On 
Feeding behavior, food reward

(i) Higher cortical regions

(ii) The anterior cingulated neocortex

(iii) The orbitofrontal cortex

(iv) Midbrain/mesolimbic reward system

Neuroendocrine and metabolic signals

(i) Hypothalamus

(ii) Hindbrain

(iii) Nucleus tractus solitarius

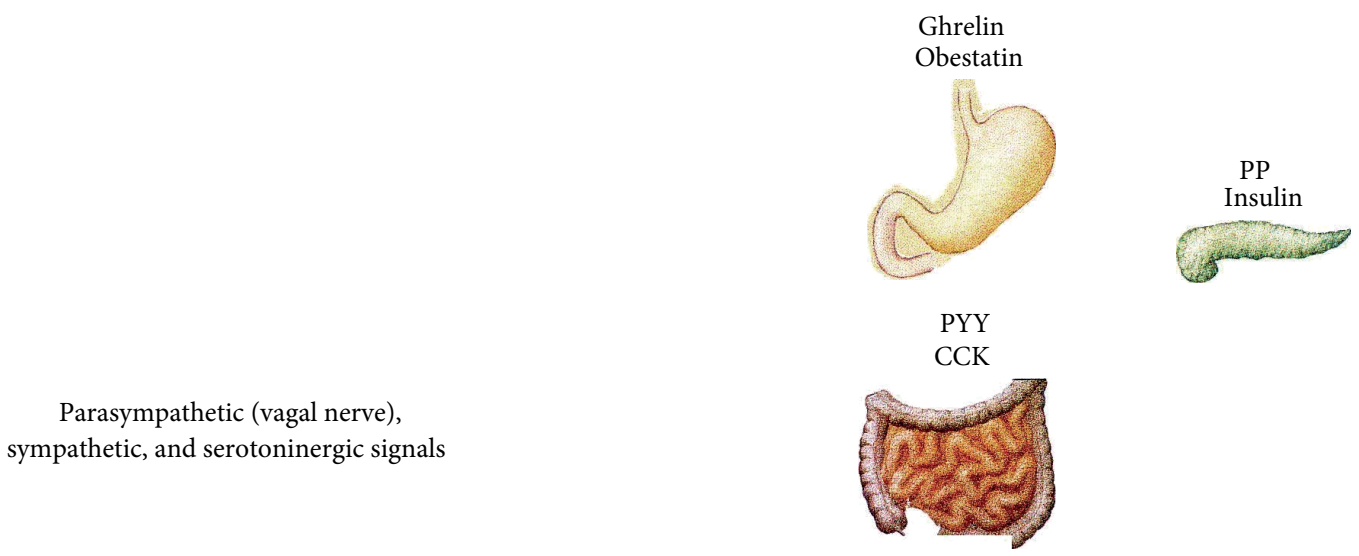

Gut

Short-term signals

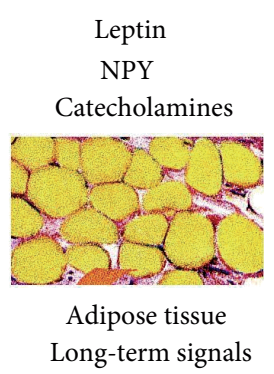

FIGURE 1: The role of adipose tissue- (AT-) gut-brain axis peptides in long-term and short-term regulation of food intake. Long-term regulators are adipose-derived food intake-inhibiting hormone leptin or food intake-stimulating hormone neuropeptide Y (NPY) mainly produced by the hypothalamus and also cosecreted with synthesized catecholamines in AT. Hormones produced in the gut are short-term food intakestimulating hormone ghrelin, or food intake-inhibiting peptide YY (PYY), pancreatic polypeptide (PP), cholecystokinin (CCK), insulin, and putative anorexigen obestatin (the hypothalamus (violet), nucleus tractus solitarius (NTS, blue), sympathetic and serotoninergic areas (red), and vagal nerve parasympathetic area (green)).

the other hand, anorexigenic cholecystokinin (CCK), peptide YY (PYY), leptin, and putative anorexigenic hormone obestatin have an opposite effect at the hypothalamic level $[16,17]$. The differential release of these hormones may act to initiate, maintain, or exacerbate cycles of food restriction or binge-purge behavior observed in AN and BN [18] (Tables 1 and 2). The former observations and recent reviews have suggested that AN and BN are linked to disturbed dopamine and serotonin systems $[3,19-23]$ which are related to anxiety, mood, and impulse control in patients with $\mathrm{AN}$ and $\mathrm{BN}$. The inverse relationship between brain serotonin system and plasma ghrelin levels, hypothalamic NPY, and cocaineamphetamine-regulated transcript (CART) expression in the regulation of feeding behavior was described in mice [24].

The abnormal eating behavior resulting in weight loss or weight gain contributes to an imbalance of energy metabolism and in vivo altered lipolysis and lipogenesis. Bradley et al. [25] hypothesized that orexigenic (appetite stimulating) 
TABLE 1: Summary of the most relevant changes of adipose tissue-gut-brain axis plasma peptides stimulating appetite and autoantibodies against acylated ghrelin before and after refeeding in patients with anorexia nervosa (AN) and bulimia nervosa (BN), and the presence of autoantibodies against neuropeptide Y (NPY) and ghrelin in healthy women and autoantibodies against NPY in depressive disorder. Immunoglobulin (Ig) M, IgG, and IgA classes.

\begin{tabular}{|c|c|c|c|c|}
\hline \multirow{2}{*}{$\begin{array}{l}\text { Peptides stimulating hunger and food intake and autoantibodies against peptides and } \\
\text { autoantibodies against neurotransmitters }\end{array}$} & \multicolumn{2}{|c|}{ AN } & \multicolumn{2}{|c|}{$\mathrm{BN}$} \\
\hline & $\begin{array}{l}\text { Acute } \\
\text { phase }\end{array}$ & $\begin{array}{l}\text { Weight } \\
\text { restored }\end{array}$ & $\begin{array}{l}\text { Acute } \\
\text { phase }\end{array}$ & Recovered \\
\hline NPY & $\rightarrow \uparrow \downarrow$ & $\rightarrow \downarrow$ & $\uparrow \rightarrow$ & $\rightarrow \uparrow$ \\
\hline NPY (response to test meal) & blunted & & $\downarrow /$ blunted & \\
\hline NPY (response to the exercise) & & & $\uparrow$ & \\
\hline \multicolumn{5}{|l|}{ Autoantibodies against NPY in healthy women (IgG, IgA) } \\
\hline \multicolumn{5}{|l|}{ Autoantibodies against NPY in depressive disorder $(\operatorname{IgG} \downarrow)$} \\
\hline Ghrelin & $\uparrow$ & $\uparrow \rightarrow$ & $\rightarrow \uparrow$ & $\rightarrow$ \\
\hline Ghrelin (response to test meal) & $\downarrow /$ blunted & & $\downarrow /$ blunted & \\
\hline Ghrelin (response to the exercise) & & & $\downarrow$ & \\
\hline \multicolumn{5}{|l|}{ Autoantibodies against ghrelin in healthy women (IgG, $\operatorname{IgA}$ ) } \\
\hline Autoantibodies against acylated ghrelin (IgM) & $\downarrow$ & $\uparrow$ & & \\
\hline Autoantibodies against dopamine, dopamine-beta-hydroxylase, and serotonin (IgG, $\operatorname{IgM})$ & & & $\downarrow$ & \\
\hline
\end{tabular}

$\uparrow$ : higher than healthy controls, $\downarrow$ : lower than healthy controls, and $\rightarrow$ : not different from healthy controls.

TABLE 2: Summary of the most relevant changes of adipose tissue-gut-brain axis plasma peptides inhibiting appetite in patients with anorexia nervosa (AN) and bulimia nervosa (BN), and the presence of autoantibodies against leptin and peptide YY (PYY) in healthy women. Cholecystokinin (CCK), immunoglobulin (Ig) G, and IgA classes.

\begin{tabular}{|c|c|c|c|c|}
\hline \multirow{2}{*}{$\begin{array}{l}\text { Peptides inhibiting hunger and food intake and } \\
\text { autoantibodies against peptides }\end{array}$} & \multicolumn{2}{|c|}{$\mathrm{AN}$} & \multicolumn{2}{|c|}{$\mathrm{BN}$} \\
\hline & $\begin{array}{l}\text { Acute } \\
\text { phase }\end{array}$ & $\begin{array}{l}\text { Weight } \\
\text { restored }\end{array}$ & $\begin{array}{l}\text { Acute } \\
\text { phase }\end{array}$ & Recovered \\
\hline Leptin & $\downarrow$ & $\rightarrow$ & $\rightarrow \downarrow$ & $\rightarrow$ \\
\hline Leptin (response to test meal) & $\rightarrow$ & & $\rightarrow$ & \\
\hline Leptin (response to the exercise) & $\downarrow$ & & $\downarrow$ & \\
\hline \multicolumn{5}{|c|}{ Autoantibodies against leptin in healthy women (IgG, IgA) } \\
\hline CCK & $\uparrow \rightarrow$ & $\rightarrow$ & $\downarrow \rightarrow$ & $\downarrow \rightarrow$ \\
\hline CCK (response to test meal) & $\uparrow \rightarrow$ & $\rightarrow$ & $\downarrow /$ blunted & \\
\hline $\mathrm{PYY}_{3-36}$ & $\rightarrow \uparrow \downarrow$ & & $\rightarrow$ & $\uparrow \rightarrow$ \\
\hline $\mathrm{PYY}_{3-36}$ (response to test meal) & $\uparrow /$ blunted & $\rightarrow$ & $\downarrow /$ blunted $/ \uparrow$ & \\
\hline \multicolumn{5}{|c|}{ Autoantibodies against PYY in healthy women (IgG, IgA) } \\
\hline Obestatin & $\uparrow \rightarrow$ & $\downarrow$ & $\rightarrow \uparrow$ & \\
\hline Obestatin (response to test meal) & $\downarrow \rightarrow$ & & $\downarrow \rightarrow$ & \\
\hline
\end{tabular}

$\uparrow$ : higher than healthy controls, $\downarrow$ : lower than healthy controls, and $\rightarrow$ : not different from healthy controls.

neuropeptides promote positive energy balance and may potentially have antilipolytic properties, whereas anorexigenic (appetite-suppressing) neuropeptides promote weight loss and may stimulate lipolysis. The role of neuropeptides in mediating lipolysis and lipogenesis in humans is not well understood. Furthermore, sympathetic nervous system (SNS) and its neurotransmitter norepinephrine (NE) play a major role in regulation of AT lipolysis, appetite, energy expenditure, and the secretion of adipocytokines [26-30]. Very recently, it was revealed that the sympathetic innervation of AT is not only a source of catecholamines because adipocytes have the capacity to produce both NE and epinephrine [31] and that various stressors are able to stimulate production of catecholamines in adipocytes [32].

In our previous studies, we observed in vivo increased SNS activity in subcutaneous abdominal AT in AN and $\mathrm{BN}$ patients $[6,33-36]$. The cause and pathogenesis of AN and $\mathrm{BN}$, however, remain unknown. The existence of a complex neurotransmitter-neuropeptide pathology in AN and $\mathrm{BN}$ could explain the pathogenesis of individuals with the eating disorder [21-23, 37-42]. From the point of view of etiopathogenesis of $\mathrm{AN}$ and $\mathrm{BN}$, it would be of interest to study the autoantibodies that react with neuropeptides and neurotransmitters which play an important role in eating 


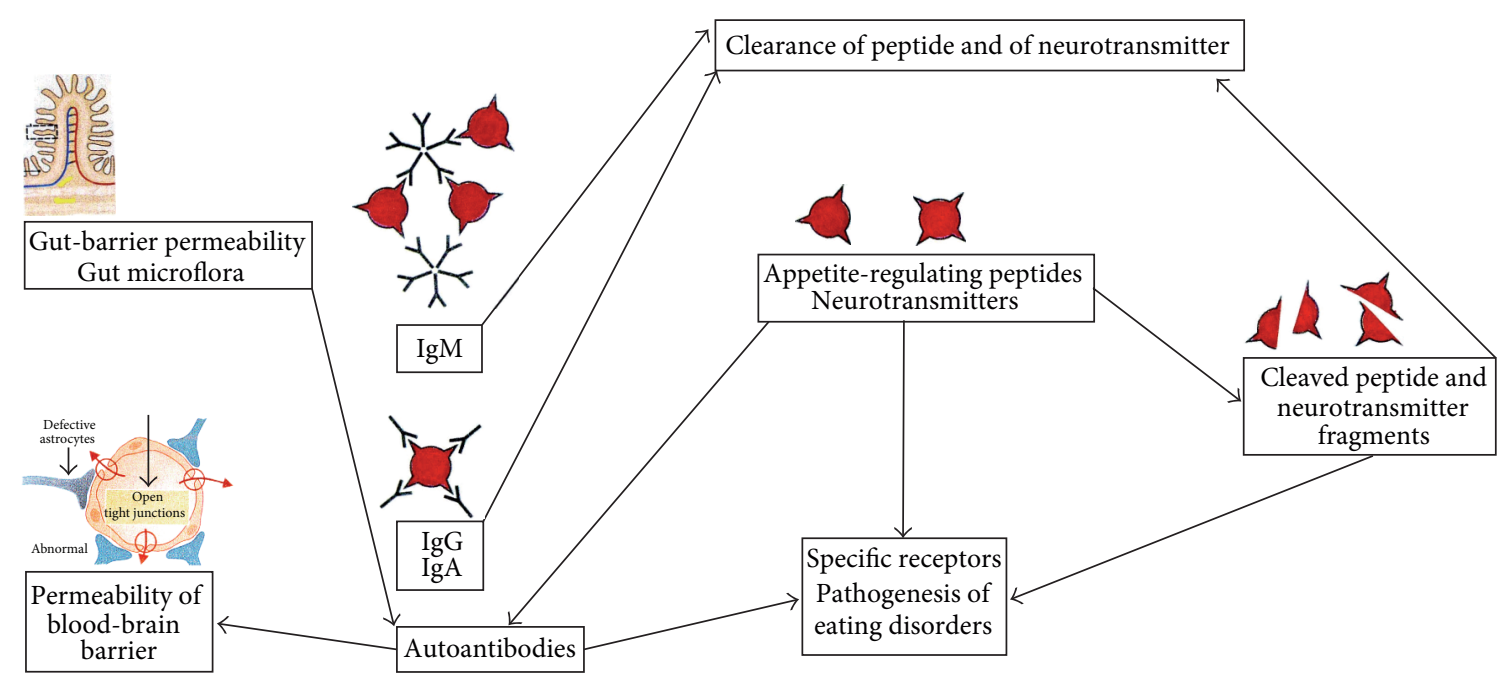

FIGURE 2: The role of up- or downregulated neutralizing autoantibodies (immunoglobulin (Ig) M, IgG, and IgA classes, and changes of their affinity) directed against appetite-regulating neuropeptides and peptides and neurotransmitters (dopamine, dopamine-beta-hydroxylase, and serotonin) in neuropeptidergic transmission and the pathogenesis of eating disorders. Producing excess of free fatty acids (FFA) and ketones to increase the permeability of the blood-brain barrier and to enter the cerebral matter in AN and BN [103]. Starvation, stress, catecholamines, microbial antigens, poststreptococcal autoimmune process (PANDAS), and proinflammatory cytokines decrease blood-brain barrier integrity in parallel with decreased levels of the tight junction protein, occludin [104]. Also autoantibodies against appetite-regulating peptides and neurotransmitters may disrupt the blood-brain barrier and the gut-barrier permeability in AN and BN [268]. Furthermore, gut-related antigens including gut microflora may influence production of specific autoantibodies (IgA class) against appetite-regulating hormones [47]. Indeed, starvation decreases the gut-barrier permeability in AN [102] and may decrease ghrelin autoantibodies (IgM, IgG, and IgA classes) production. However, realimentation-induced changes in the gut-barrier permeability and new antigenic stimulation during refeeding were accompanied by an increase of acylated ghrelin autoantibodies (IgM class) in AN [48].

behavior, appetite control, and immunoregulatory system in $\mathrm{AN}$ and BN. Indeed, Corcos et al. [43] hypothesized that dopamine, dopamine-beta-hydroxylase, and serotonin acting with autoantibodies could be the antigenic cerebral targets reacting with "anti-brain" antibodies in BN. All autoantibodies against dopamine, dopamine-beta-hydroxylase (i.e., the enzyme that synthesizes NE from dopamine), and serotonin were lower in BN than in the controls (Table 1). Moreover, the autoantibodies directed against feeding-stimulatory and feeding-inhibitory neuropeptides have been reported in patients with AN and BN. These autoantibodies correlated with psychopathological traits in individuals with eating disorders [44-46] and that neutralizing autoantibodies directed against appetite-regulating peptides were classified as important attributors to mechanisms controlling motivation in AN and BN (Figure 2). Fetissov et al. [47] studied healthy women for the presence of autoantibodies directed against 14 key appetite-regulating neuropeptides or peptide hormones including NPY, ghrelin, leptin, or PYY (Tables 1 and 2). Thus, these results confirmed that autoantibodies against hormones represent a general physiological phenomenon, suggesting its implication in physiological peptidergic transmission. The detection of the immunoglobulin (Ig) A class of such autoantibodies supports the antigenic stimulation by gut microflora in healthy subjects [47] (Figure 2). In fact, patients with AN display increased plasma levels of alphamelanocyte-stimulating hormone $(\alpha-\mathrm{MSH})$ autoantibodies
[45] contrasting with lower levels in acylated ghrelin autoantibodies [48] (Table 1). The presence of immune complexes sequesters autoantibodies against nonacylated ghrelin resulting in higher levels of free acylated ghrelin in AN patients, and eventually resulting in ghrelin resistance in AN [48]. Intriguingly, this is a potentially analogous situation in which autoantibodies against insulin may play a role in the shifts of bioavailable levels of insulin with possible effects on hypoglycemia. Involvement of insulin autoantibodies in insulin resistance has been extensively studied as a mechanism underlying insulin resistance after insulin administration [49] and autoantibodies against insulin have been studied as a marker of type 1 diabetes [50]. Using homeostasis model assessment of insulin resistance (HOMA-IR), we found significantly lower values of HOMA-IR in malnourished and underweight AN patients when compared with the controls $[28,29]$. However, refeeding is associated with the onset of insulin resistance in AN patients [51].

The aim of this review was to describe the key role of orexigenic and anorexigenic hormones originating from the gut, central nervous system, and AT and to discuss how an impairment of energy balance and interaction between these factors and up- or downregulated neutralizing autoantibodies are involved in the pathogenesis, autoimmunity, regulation of food intake, energy expenditure, and growth hormone (GH) release in eating disorders. Understanding of the pathogenic mechanisms may contribute to more specific and effective therapy in $\mathrm{AN}$ and $\mathrm{BN}$. 


\section{An Overview of Hunger-Satiety Signals and Autoantibodies against Appetite-Regulating Neuropeptides and Peptides of the AT-Gut-Brain Axis}

2.1. Ghrelin. Ghrelin is a 28 -amino acid peptide which increases food intake and acts as an endogenous stimulator of GH [52]. The ghrelin gene encodes a polypeptide preproghrelin containing 117 residues which undergoes stepwise processing to form ghrelin [53]. Ghrelin is predominantly produced by the stomach but is also expressed in many other tissues and is the first identified hormone containing acylated n-octanoic acid in its residues by ghrelin-O-acyl-transferase (GOAT) $[54,55]$. This acylation is essential for binding to the growth hormone secretagogue (GHS) receptor type la (GHS-R la) and for the GH-releasing and appetite-stimulating activities. Genetic variation of GOAT is implicated in the etiology of AN [56]. Unexpectedly to the ghrelin secretion pattern, it was shown that GOAT mRNA levels decrease upon prolonged food deprivation and increase postprandially. Therefore, GOAT-ghrelin system may also act as a nutrient sensor by using readily absorbable medium-chain fatty acids to signal to the brain that high caloric food is available [57] and that dietary lipids can directly influence ghrelin acylation.

The effect of ghrelin on GH release is two to three times greater than that of GH-releasing hormone (GHRH) in humans [58]. Moreover, peripherally administered ghrelin signals via the vagus nerve to the brain where it triggers the release of GHRH and contributes to the activation of the food intake signalling cascade by NPY neurons in the arcuate nucleus of the hypothalamus [59]; when the vagus nerve is cut, the induction of GH release after ghrelin injection is dramatically decreased. It was documented that GH inhibits stomach ghrelin secretion. These findings indicate that the vagal circuit between the brain and the stomach has a crucial role in regulating plasma ghrelin levels [60]. Asakawa et al. [61] indicated that in contrast to acylated ghrelin, nonacylated ghrelin induces a negative energy balance by decreasing food intake and delaying gastric emptying. Nonacylated ghrelin present in plasma in far greater quantities than acylated ghrelin seems to be devoid of any endocrine action. However, it is able to exert some nonendocrine actions including cardiovascular and antiproliferative effects by binding different GHS-R subtypes [62]. It was described that acylated ghrelin [63] and nonacylated ghrelin pass the blood-brain barrier by means of transmembrane diffusion [64]. Nonacylated ghrelin induces an increase in neuronal activity in the arcuate nucleus, is involved in the regulation of the synthesis of anorexigenic mediators like urocortin and CART in the hypothalamus, and interacts with the corticotropin releasing factor receptor subtype $2\left(\mathrm{CRF}_{2}-\mathrm{R}\right)$. Therefore, the neuromodulatory peptides CART and urocortin might thus play a key role in the anorexigenic effect of nonacylated ghrelin via $\mathrm{CRF}_{2}$-R-dependent signalling [65].

The role of acylated ghrelin, nonacylated ghrelin, and other ghrelin gene-derived peptides in the postprandial regulation of satiety was not established. Recently, we found decreased levels of plasma total, acylated, and nonacylated ghrelin and obestatin after a high-carbohydrate breakfast in healthy women [66]. It is possible that obestatin may postprandially blunt the effect of ghrelin in healthy normal weight women.

Ghrelin increases food intake through effects on NPY [67]. Recently, studies in rodents suggested a possible mediation of ghrelin action on GH by NPY and that GH may be involved in maintaining feeding [68]. Plasma ghrelin levels are elevated during fasting and suppressed after meal. It was shown that the efferent vagus nerve contributes to the fastinginduced increase in ghrelin secretion and that higher ghrelin stimulates the afferent vagus nerve, promotes food intake, and contributes to ghrelin-induced GH secretion. These findings demonstrate that the vagal circuit between the brain and stomach has an important role in regulating plasma ghrelin levels [60]. Peripheral ghrelin signalling, which travels to the nucleus tractus solitarius (NTS) in part via the vagus nerve, increases NE in the arcuate nucleus of the hypothalamus, thereby stimulating feeding, at least partially through alpha ${ }_{1}^{-}$ and beta $_{2}$-noradrenergic receptors [69]. Furthermore, ghrelin may have an integrative role in the behavioral and an adaptive response to starvation by increasing anxiety and alertness in animals and humans [70]. Ghrelin is also a potent secretagogue for $\mathrm{GH}$ and an intravenous (i.v.) ghrelin administration stimulates GH release in a dose-dependent fashion in humans [71], and there may be a positive association mediated by ghrelin, alternatively, a negative feedback action such that inhibition of plasma ghrelin levels occurs when plasma GH levels are high [72].

Fasting plasma ghrelin concentrations in humans are negatively correlated with body mass index (BMI) [73]. In obese individuals, dieting is associated with an increase in plasma ghrelin levels [74]. Both peripherally and centrally administered ghrelins produce a positive energy balance and lead to body weight gain [75]. In humans, acylated ghrelin induces a rapid rise in blood glucose and plasma insulin levels. However, coadministration of nonacylated ghrelin counteracts this effect. A separate i.v. administration of nonacylated ghrelin improves glucose metabolism and insulin sensitivity and inhibits lipolysis in humans [76]. Based on these data, Van Der Lely [76] suggests the existence of a specific receptor for nonacylated ghrelin other than $\mathrm{CRF}_{2}-\mathrm{R}$ and GHS-R 1a.

Current analysis has the expression of ghrelin in a number of endocrine tissues such as AT [77]. Recently, Liu et al. [78] have explored the effects of ghrelin on the proliferation and differentiation of preadipocytes in vitro and confirm that ghrelin induces the differentiation of 3T3-L1 preadipocytes into mature adipocytes. Rodent and human studies indicate that ghrelin elicits an antilipolytic effect mediated by both acylated and nonacylated ghrelin and promotes adipogenesis [79]. However, predominant nonacylated ghrelin does not appear to activate GHS-Rla, and it remains unclear through which receptor nonacylated ghrelin mediates its action in AT, although it has been suggested that the antilipolytic effect of ghrelin could be mediated by an unidentified non-GHS-R la receptor [80]. Interestingly, the ratio of acylated and nonacylated ghrelin production might help to regulate the balance between adipogenesis and lipolysis in response to nutritional status [81]. Recently, Tebbe et al. [82] have shown that ghrelin 
effects in the rat central nervous system appear to be mediated through receptor $\mathrm{Y} 1$, which also mediates the antilipolytic action of $\mathrm{NPY}_{1-36}$ and PYY ${ }_{1-36}$. Thus, ghrelin may mediate its peripheral action in AT through Y1 receptor. Kos et al. [83] have demonstrated antilipolytic action of ghrelin in human AT and showed that acylated and nonacylated ghrelin may be ligands for Y1 mediating lipogenic effect in humans.

\subsubsection{Ghrelin Levels and Autoantibodies against Ghrelin before} and after Realimentation in $A N$ and BN. Fasting plasma ghrelin levels have been reported to be increased in underweight patients with $\mathrm{AN}$, especially in patients with bingepurge subtype of AN as compared to patients with restrictive type of AN, suggesting that binge-purging behavior has some influence on plasma ghrelin [84, 85] (Table 1). These findings were not confirmed by Otto et al. [86], who did not find difference in plasma ghrelin between restrictive and binge-purge subtypes of AN, and by Troisi et al. [87], who detected opposite results with higher plasma ghrelin levels in restrictive type of $\mathrm{AN}$ as compared to patients with bingepurge subtype of AN and BN individuals. Ghrelin is increased in the case of $\mathrm{AN}$, and this increase in plasma ghrelin levels may occur either as an adaptive response to correct the abnormal energy status or as a result of relative resistance to ghrelin [88].

A greater fall of plasma ghrelin levels was seen in AN than normal controls following an euglycemic hyperinsulinemic clamp [89]. In women with AN, Karczewska-Kupczewska et al. [89] reported significant positive correlation between fasting ghrelin and insulin sensitivity and that the progressive decline in circulating insulin would favor ghrelin production in AN [84]. The enhanced plasma ghrelin levels of underweight AN patients tend to normalize after refeeding [90]. Furthermore, patients with AN do not show a decrease in plasma ghrelin following a standardized meal that is observed in healthy women [91], and anorectic patients would be refractory to the orexigenic action of ghrelin to regain a normal weight and replenish energy stores (Table 1).

Furthermore, our group assumes that the preproghrelin is cleaved differently in eating disorders such as AN than under physiological conditions. Thus, intact acylated ghrelin 1-28 is rapidly degraded to nonacylated forms or smaller fragments in AN patients. Alternatively, a loss of function mutations in GOAT might disturb the ratio of acylated ghrelin to nonacylated ghrelin [56]. These hypotheses are in keeping with the finding of Hotta et al. [92] who reported decreased levels of plasma acylated ghrelin in AN patients. However, Germain et al. [93] documented that the acylated ghrelin/total ghrelin ratio has been found to be increased in the restrictive type of $\mathrm{AN}$, whereas it decreased in the binge-purge type of AN and $\mathrm{BN}$.

$\mathrm{GH}$ levels are higher in patients with AN than in controls, and these higher levels are consequent to higher levels of ghrelin, a GH secretagogue. Thus, the hypersecretion of ghrelin might contribute to the hypersomatotropism of AN [94]. Indeed, a dysfunction of the ghrelin feedback systems might lead to the pathophysiology of AN and BN [60]. Furthermore, Støving et al. [95] suggest that $\mathrm{GH}$ hypersecretion in $\mathrm{AN}$ is due to decreased hypothalamic somatostatinergic tone restored by weight gain in these patients.

The physiological inhibitory role of free fatty acids (FFA) on GH secretion seems to be preserved in patients with AN. In fact, the infusion of FFA inhibited the elevated basal $\mathrm{GH}$ levels and abolished the exaggerated $\mathrm{GH}$ response to the GHRH, whereas the administration of antilipolytic drug Acipimox (Aci) led to the decrease in plasma FFA and markedly enhanced the GHRH-induced GH rise in patients with AN but not in healthy women [96]. Although patients with AN showed a hyperresponsiveness to GHRH administration [95], their $\mathrm{GH}$ response to ghrelin administration is surprisingly blunted [97]. This finding is consistent with desensitization of the GHS receptor induced by the chronic elevation of ghrelin levels in AN or impaired metabolic status in AN because ghrelin administration was not followed by increase in blood glucose levels in these patients [97]. Indeed, $\mathrm{AN}$ is associated with a nutritionally acquired resistance to $\mathrm{GH}$ with elevated $\mathrm{GH}$ levels, and low levels of the GH-binding protein indicate decreased expression of the $\mathrm{GH}$ receptor, which accounts for the state of $\mathrm{GH}$ resistance in the starved state [98]. This is consistent with results reported by Fazeli et al. [99] that administration of supraphysiological recombinant human $\mathrm{GH}$ in patients with $\mathrm{AN}$ does not overcome the state of $\mathrm{GH}$ resistance. Therefore, the administration of recombinant human $\mathrm{GH}$ was not associated with a significant change in plasma levels of blood glucose, insulin, or FFA in AN. Importantly, these findings suggest that patients with AN would have a relatively high resistance to the effects of $\mathrm{GH}$ [99]. In AN, a greater mobilization of FFA leads to an increase in the peroxisome proliferator-activated receptoralpha (PPAR- $\alpha$ ) which increases levels of fibroblast growth factor 21 (FGF 21) [100]. In fact, FGF 21 is a novel adipocytokine which may mediate $\mathrm{GH}$ resistance and reduces insulin growth factor 1 (IGF-1) levels in AN [101]. Patients with AN display low levels of autoantibodies against acylated ghrelin and higher levels of autoantibodies against nonacylated ghrelin present as immune complexes. Interestingly, the negative correlations were found between plasma autoantibodies and ghrelin peptides, and the decrease of bioavailable ghrelin autoantibodies may underlie an increase of plasma ghrelin levels and the resulting phenomenon of ghrelin resistance in patients with $\mathrm{AN}$ [48]. Indeed, starvation-induced changes decreased gut-barrier permeability [102] and may decrease ghrelin autoantibodies (IgM, IgG, and IgA classes) in AN. However, Terashi et al. [48] found that refeeding in $\mathrm{AN}$ patients was accompanied by an increase of acylated ghrelin autoantibodies (IgM class), which may indicate new antigenic stimulation leading to realimentation-induced changes in the gut-barrier permeability in AN patients (Table 1, Figure 2). In contrast to the decreased gut-barrier permeability during starvation in AN, increased levels of plasma FFA and the more ketone bodies produced increase the permeability of the blood-brain barrier during starvation and weight loss in patients with AN [103]. Moreover, starvation, stress, catecholamines, microbial antigens, poststreptococcal autoimmune process (PANDAS), and proinflammatory cytokines decrease blood-brain barrier integrity in parallel with decreased levels of the tight junction protein, occludin [104] 
(Figure 2). Hence, it is possible that access of high affinity autoantibodies against appetite-regulating neuropeptides and peptides in the brain centers normally protected by the blood-brain barrier may trigger the development of AN and $\mathrm{BN}$ (Figure 2).

It is accepted that plasma levels of active acylated ghrelin represent less than $10 \%$ of circulating total ghrelin levels, which include acylated and inactive nonacylated ghrelin. We found increased plasma nonacylated ghrelin but not acylated ghrelin levels in AN patients (unpublished data). While high plasma total ghrelin in AN has been consistently observed $[91,105]$, elevated acylated ghrelin was found in few studies $[106,107]$.

It was reported that fasting plasma ghrelin was higher in the purging type of $\mathrm{BN}$ in comparison to the nonpurging type and in comparison to controls $[108,109]$; this supports the idea that binge-purge cycles have an influence on fasting plasma ghrelin. However, subsequent studies did not detect any significant difference in plasma ghrelin levels between binge-purge $\mathrm{BN}$ patients and controls $[12,13,87,110]$ though Kojima et al. [111] found that $\mathrm{BN}$ patients exhibited elevated ghrelin levels despite higher BMI. In our recent studies, we reported increased response of $\mathrm{GH}$ and ghrelin to shortterm exercise and antilipolytic drug Aci in BN patients and confirmed that GH exerted an inhibitory feedback effect on plasma ghrelin during exercise only in BN patients but in both BN patients and healthy women during exercise with Aci administration $[12,13]$. Therefore, these data established ghrelin as a potential discriminator between women with eating disorders and healthy women [87]. Furthermore, the ghrelin responses to a standardized meal have been reported to be blunted in symptomatic binge-purge $\mathrm{BN}$ patients as compared to healthy controls [110-112]. However, in our recent study, we documented decreased ghrelin levels in $\mathrm{BN}$ patients after a high-carbohydrate breakfast [11] (Table 1).

In contrast with anorectic patients, the normal $\mathrm{GH}$ response to ghrelin administration was observed in $\mathrm{BN}$ patients, and ghrelin administration was followed by increase in blood glucose in BN [113]. These authors hypothesize that ghrelin hypersecretion may have a role in eating behavior but normal GH and blood glucose response to ghrelin administration may reflect less impaired nutritional status in $\mathrm{BN}$ patients [113].

2.2. Obestatin. Recently, it has been demonstrated that preproghrelin undergoes additional proteolytic cleavage, generating a 23-amino acid peptide, which has been named obestatin, and amidation of obestatin is likely essential for its biological activity as well as acylation of ghrelin. Responses to obestatin ${ }_{1-23}$ were greater than those to obestatin ${ }_{1-10}$ and obestatin $_{11-23}$ [114]. Unlike ghrelin, treatment with obestatin did not increase GH secretion [17]. Interestingly, obestatin antagonized GH secretion and food intake induced by ghrelin only when ghrelin and obestatin were coadministered [115]. Fasting obestatin levels were significantly lower in obese patients than in normal weight and anorectic women [116], and significant increase of both plasma obestatin and ghrelin levels was demonstrated with weight loss in obese patients
[117]. In contrast to ghrelin, obestatin has anorexigenic effects, reduces gastric emptying, inhibits jejunal contractions, and suppresses body weight gain [17]. However, several recent studies performed in rats and mice under various experimental conditions did not reproduce these results [118, 119] and did not support the concept that obestatin is an opponent or counterpart of ghrelin. Indeed, Gourcerol et al. [118] proposed to rename obestatin to ghrelin-associated peptide. It was revealed that the action of obestatin on the secretion of insulin, glucagon, and somatostatin is the same as the action of acylated ghrelin [120].

Further studies showed that obestatin was involved in inhibiting thirst and vasopressin secretion [121], affecting cell proliferation [122], increasing the secretion of pancreatic juice enzymes [123], and inhibiting glucose-induced insulin secretion [124]. Although Zhang et al. [17] implied that amidation of obestatin is essential for obestatin activity, Van Dijck et al. [119] did not demonstrate any suppressive effects on eating and drinking after central administration in mice despite using amidated obestatin. Interestingly, Pan et al. [125] reported that obestatin is unable to cross the blood-brain barrier and is rapidly degraded in the circulation; this was confirmed by Vergote et al. [126]. Therefore, an alternative hypothesis is that obestatin exerts its effects on eating and drinking through direct interactions with the gastrointestinal system. Indeed, Zhang et al. [17] observed decreased contractile activity of jejunum muscle strips in vitro and suppression of gastric emptying in vivo after obestatin treatment. Thus, the inhibition of jejunal contraction could generate an afferent vagal signal to induce satiety in the brain. Obestatin is an interesting peptide but controversial gut hormone. It was concluded that obestatin exerts a dual effect on glucose-induced insulin secretion. At a low glucose concentration, obestatin potentiated the insulin response to glucose. At a high glucose concentration, obestatin inhibited the insulin release [127].

In our previous study, Sedláčková et al. [66] demonstrated that plasma obestatin levels decrease similarly to ghrelin after a high-carbohydrate breakfast in healthy women. A possible explanation of the simultaneous postprandial decrease of obestatin with ghrelin is that the function of obestatin may be to antagonize orexigenic ghrelin action after food intake. Interestingly, obestatin was positively correlated to total ghrelin, nonacylated ghrelin, and NPY. The positive relationship of obestatin with total ghrelin in the postprandial period indicates that these two cleavage products of one gene could act in a similar fashion to increase food intake. This idea is confirmed by the positive correlation between obestatin and orexigen NPY. However, this positive relationship of obestatin with the nonacylated ghrelin may correspond with the idea of a dual effect of obestatin.

Zhang et al. [17] reported that obestatin was the cognate ligand for the orphan G-protein-coupled receptor 39 (GPR39) based on the claim of its binding to human GPR39 with high affinity and specificity. However, recent reports indicate that obestatin is unlikely to be the endogenous ligand for GPR39 due to the lack of specific binding on GPR39 receptor-expressing cells and the absence of signal transduction pathway activation [128]. The native receptor for obestatin remains to be identified. 
Recently, Zhang et al. [129] suggested that obestatin was a hormone capable of binding to GPR39 to regulate functions of gut and AT. Another observation revealed that the obestatin receptor GPR39 was upregulated in AT during fasting, whereas GPR39 levels were decreased in cultured mouse embryonic fibroblast cell lines (related to 3T3-L1) during adipogenesis [130]. A decreased obestatin receptor GPR39 expression in human AT was found in patients with obesity [131]. These findings suggest a possible role of the obestatin receptor GPR39 in adipogenesis. It was speculated that the obestatin receptor GPR39 could possibly play a similar role in the liver, adipose, endocrine pancreas, and gastrointestinal tract tissue regeneration and differentiation [132]. Furthermore, Granata et al. [133] documented that obestatin promotes beta cells and human islets survival by binding to glucagon-like peptide-1 (GLP-1), that is, the receptor via which incretins act. Very recently, Fujimiya et al. [134] supposed that obestatin may act on the obestatin receptor on vagal afferent nerve terminals, and CRF-R and urocortin2 neurons in the hypothalamus may mediate the action of obestatin to inhibit the gastroduodenal motility via $\mathrm{CRF}_{1}-\mathrm{R}$ and $\mathrm{CRF}_{2}-\mathrm{R}$ in the brain.

2.2.1. Obestatin Levels in AN and BN. Recently, Sedlackova et al. [11] documented that fasting plasma obestatin levels were increased in both $\mathrm{AN}$ and $\mathrm{BN}$ patients compared to controls (Table 2). Monteleone et al. [135] found that underweight AN patients displayed increased plasma obestatin and ghrelin levels and an increased ghrelin/obestatin ratio compared with healthy women, which may suggest that the hunger signal of ghrelin is stronger than the satiety signal of obestatin. A limitation of this study is represented by the low number of ANrestrictive patients with respect to AN binge-purge individuals because in AN binge-purge subjects ghrelin levels have been reported to be higher than in AN-restrictive ones [109]. In addition, Zamrazilová et al. [116] failed to reveal any significant differences in plasma obestatin levels between restrictive type of AN and normal weight women, but the higher ghrelin to obestatin ratio in $\mathrm{AN}$ might reflect a long-term reduction in energy intake which could contribute to susceptibility of AN women to bulimic episodes. No significant changes in these parameters were detected in $\mathrm{BN}$ patients [135]. Moreover, Harada et al. [107] and Nakahara et al. [136] showed increased plasma obestatin and ghrelin levels in small groups of AN restrictive patients compared with age-matched healthy women. None of these studies, however, calculated the ghrelin/obestatin ratio.

Recently, Germain et al. [105] have reported increased plasma obestatin and ghrelin levels and decreased ghrelin/obestatin ratio in restrictive AN. The decreased ghrelin/obestatin ratio could facilitate the food intake restriction in these patients if obestatin inhibitory effects on food regulation were more validated.

However, Sedlackova et al. [11] reported that the administration of a high-carbohydrate breakfast induced a similar relative decrease in plasma ghrelin and obestatin in $\mathrm{AN}, \mathrm{BN}$ patients and the controls suggesting a role of obestatin with rather orexigenic properties (Table 2). Moreover, we found that the ghrelin/obestatin ratio was lower in $\mathrm{AN}$ compared to $\mathrm{BN}$ and controls. We suggested that different plasma obestatin levels in AN and BN may have demonstrated their diverse function in eating behavior. Germain et al. [93] revealed that total and acylated ghrelin and obestatin circadian levels are increased in patients with AN restrictive type compared with the controls but decreased in patients with AN binge eating/purging type and those with BN. Recently, Uehara et al. [137] reported that an increase in energy intake leads to a decrease in plasma obestatin levels in patients with AN restrictive type (Table 2 ).

2.3. NPY. NPY is a 36 -amino acid peptide that has potent orexigenic properties [138]. Experimental evidence indicates that NPY is the strongest orexigenic factor in the hypothalamic control of feeding behavior [139]. NPY's activity in cellular metabolism is mediated through binding to G-proteincoupled receptors, of which at least four subtypes exist in humans (Y1, 2, 4, and 5) and which are present in most peripheral tissues. The hypothalamic Y1, Y2, Y4, and Y5 receptors have all been hypothesized to mediate the orexigenic effects of NPY [140].

NPY coexists with catecholamines in the central and SNS and in the adrenal medulla [141]. In coculture with adipocytes, sympathetic neurons secreted NPY, suggesting cross-talk between the neural cells and adipocytes [142]. Furthermore, NPY-containing nerves are present in the gut of many species. Orexigenic peptide NPY participates in ghrelin and GH regulation pathways [143]. Coiro et al. [144] revealed that a somatostatinergic pathway is involved in the mechanism connecting physical exercise to NPY secretion in humans. Even though plasma NPY levels do not reflect NPY secretion in the central nervous system, there is no clear evidence that plasma NPY levels originate from peripheral sympathetic nerve secretion or the adrenal gland and/or AT during exercise in humans [145].

The i.v. administration of NPY has no effect on GH secretion in healthy humans [146]. However, stimulatory effects of NPY on GH secretion have been reported in prolactinoma and acromegalic patients $[147,148]$. In addition, some of these authors also described inhibition of GH secretion by NPY [148].

The role of NPY can be considered as helping to coordinate protective antistarvation activity and preventing further depletion of existing energy stores. Antilipolytic effect of NPY may also regulate plasma FFA. As FFA regulate insulin sensitivity, an impairment in NPY's antilipolytic action could lead to changes in insulin resistance [149].

Intracerebroventricular injection of NPY appears to mediate upregulation of the key enzyme of lipogenesis: lipoprotein lipase expression and activity in AT [150]. It was recently found that NPY is synthesized in human AT and stimulates the proliferation and differentiation of new adipocytes $[151,152]$. Thus, AT-derived NPY could cause a significant rise of plasma NPY levels and may mediate reduction of leptin secretion [151]. Although to date the role of most of these receptors in human AT is poorly understood, binding studies [25] have suggested that Y1 receptor may mediate the antilipolytic effect of NPY in AT. NPY ${ }_{1-36}$ is cleaved by dipeptidyl peptidase IV (DPP-IV) to generate the truncated 
$\mathrm{NPY}_{3-36}$, with which DPP-IV diverts affinity of NPY from $\mathrm{Y} 1$ to other receptors such as receptor Y5 whose function remains elusive [153]. DPP-IV inhibitors are therefore likely to enhance the antilipolytic action of $\mathrm{NPY}_{1-36}$ as well as PYY $_{1-36}$ [153]. Furthermore, in order to better understand the interactions between sympathetic neurotransmitters and glucocorticoids in AT, Kuo et al. [154] treated sympathetic neural cells with dexamethasone upon which the expression of NPY and its Y2 receptor was more than doubled. Therefore, cortisol and the adrenergic activity seem to converge on the NPY-Y2 adipogenic system. Thus, adipose-derived NPY may have implications for central feedback of adiposity signals.

2.3.1. NPY Levels in AN and BN. NPY is one of the primary systems regulating the stress response, emotionality, and hormones relevant to $\mathrm{AN}$ and $\mathrm{BN}$. It has been reported that NPY can attenuate specific behavior when the organism is stressed, and antistress effects of NPY are relevant to psychiatric conditions such as $\mathrm{AN}$ and $\mathrm{BN}[6,155,156]$ and that NPY has an anxiolytic and antidepressive behavior profile [157]. Interestingly, it is possible that NPY contributes to both binge eating and subsequent purging in BN because NPY itself has been demonstrated to induce an emetic response [158].

In reports with AN, basal plasma NPY levels in AN patients did not differ from the levels in the controls [159, 160]. Discordant data have been published concerning NPY levels in AN patients. Plasma levels of NPY were significantly lower in anorectic women than in the control group [161], and plasma NPY was decreased during treatment of anorectic girls. These changes do not correspond with increasing body weight suggesting dysregulation of appetite and body weight control mechanisms in AN [162]. The study by Sedlackova et al. [14] published during the preparation of this paper assumes that increased fasting NPY levels unchanged after a high-carbohydrate and high-protein breakfast indicate that NPY may be an important biomarker for disturbed eating behavior in AN and BN patients (Table 1).

Recent studies have suggested that NPY is not merely an "orexigen" but acts to stimulate behavior which precedes the food intake and actually inhibits intake per se $[163,164]$. It was found that the treatment with NPY increased physical activity, decreased food intake and caused a loss of body weight in rats [165]. From this point of view, it is possible that AN patients are physically hyperactive and eat only a little food in spite of having depleted body fat and pathologically upregulated hypothalamic orexigenic peptides [165].

Plasma levels of NPY during symptomatic and remission phases of $\mathrm{BN}$ are unchanged compared with age- and weightmatched controls [38]. However, plasma concentrations of NPY in patients with BN were significantly elevated in comparison to controls $[6,11,13,14,161]$ (Table 1). In our recent study, we revealed that antilipolytic drug Aci during shortterm exercise further increases plasma NPY levels in patients with BN [6].

2.4. PYY. PYY is a 36-amino acid gut peptide belonging to the same family as NPY, and PYY has recently been discovered in the hypothalamus of the human brain. PYY is released from the endocrine L cells of the distal ileum and colon in response to feeding [166]. PYY in the circulation exists in two major forms: $\mathrm{PYY}_{1-36}$ and $\mathrm{PYY}_{3-36}$. $\mathrm{PYY}_{3-36}$ binds with the greatest affinity at the presynaptic inhibitory $\mathrm{Y}_{2}$ receptor and is a peripherally active anorectic signal. $\mathrm{PYY}_{3-36}$ is the product of cleavage of the amino terminus

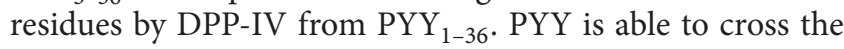
blood-brain barrier by transmembrane diffusion from the circulation [167]. Evidence suggests that the anorectic effect of peripheral $\mathrm{PYY}_{3-36}$ may be mediated via the presynaptic inhibitory $\mathrm{Y}_{2}$ receptor present on arcuate NPY neurons [168]. It was also shown that $\mathrm{PYY}_{3-36}$ inhibited dopamine and NE release through the NPY Y2 receptors in the hypothalamus supporting a central anorectic effect of PYY ${ }_{3-36}$ [169]. In contrast to peripheral $\mathrm{PYY}_{3-36}$, centrally administered $\mathrm{PYY}_{1-36}$ and PYY ${ }_{3-36}$ increase food intake. PYY injection into the third, lateral, or fourth cerebral ventricles potently stimulates food intake in rodents [170]. Therefore, while circulating, $\mathrm{PYY}_{3-36}$ may access the higher affinity arcuate nucleus $\mathrm{Y}_{2}$ receptors, and the central feeding effects of PYY ${ }_{1-36}$ and $\mathrm{PYY}_{3-36}$ may be mediated by lower affinity $\mathrm{Y}_{1}$ and $\mathrm{Y}_{5}$ receptors [16]. Circulating PYY levels are low in the fasting state and rapidly increase postprandially when PYY is released into the circulation [171]. Either central or peripheral administration of PYY reduces food intake and body weight gain in humans [168]. The role of PYY in the regulation of energy balance in humans remains to be clarified; however, reduced caloric intake was demonstrated following infusion of PYY [168]. Moreover, PYY is known to cause nausea and emesis in some individuals $[172,173]$ which can contribute to subsequent self-induced vomiting in BN. A single infusion of $\mathrm{PYY}_{3-36}$ is capable of reducing food intake in lean and obese humans and decreasing circulating ghrelin levels [174]. Thus, it appears that peripheral $\mathrm{PYY}_{3-36}$ acts as a satiety signal regulating the termination of meal, partially by decreasing the production of the hunger-stimulating plasma ghrelin. In addition, in healthy subjects, there is a negative correlation between plasma levels of ghrelin, PYY, and BMI, respectively [111]. Also a negative association between PYY and leptin levels was described. It was suggested that PYY levels increase with weight loss and when plasma leptin is low [175].

It was shown that exercise can function as a physiological regulator of hormone release in appetite control and that levels of $\mathrm{PYY}_{3-36}$ are positively correlated with exercise intensity [176, 177].

Furthermore, the antilipolytic effect of PYY and NPY has been shown in human adipocytes. Labelle et al. [178] have noted that the receptor Y1 mediates the antilipolytic effect of NPY and PYY in rat adipocytes. Current evidence supports that Y1 does not only bind to NPY ${ }_{1-36}$ but can bind other ligands of the pancreatic polypeptide family with potentially higher binding affinities for $\mathrm{PYY}_{1-36}[83]$.

2.4.1. $P Y Y$ Levels in $A N$ and $B N$. Studies of $P Y Y_{3-36}$ secretion in $A N$ and $B N$ are still scanty [179]. In patients with AN, basal plasma $\mathrm{PYY}_{3-36}$ levels have been reported to be normal [180], increased [181-183] or reduced [184]. Moreover, in anorectic patients, plasma $\mathrm{PYY}_{3-36}$ response to food intake has been detected to be time delayed [180] or increased [182] (Table 2). 
After a partial body weight regain, the $\mathrm{PYY}_{3-36}$ response to a test meal was not completely restored in AN patients [182]. Recently, Sedlackova et al. [14] documented that basal plasma PYY levels were similar in $\mathrm{AN}$ and $\mathrm{BN}$ groups and reached significantly higher values after high-protein breakfast compared with high-carbohydrate breakfast suggesting an important role of ingested macronutrient in plasma levels of PYY (Table 2).

In BN, basal plasma PYY levels increase to markedly high values during the phases of abstinence from binge eating and vomiting to return to control levels after recovery $[185,186]$. However, we and the others found that fasting plasma PYY levels during symptomatic phase of $\mathrm{BN}$ were unchanged and comparable with age- and weight-matched healthy women $[14,187]$. Recently, a blunted PYY response to food ingestion was reported in bulimic patients together with a decreased response of ghrelin $[110,111]$ (Table 2 ). What might be the role of PYY and ghrelin aberrations in BN? It has been demonstrated that $\mathrm{BN}$ patients exhibit impaired CCK secretion [188]. CCK, a satiety factor, is a stimulant of PYY secretion [189]. Hence, depressed PYY levels may result from reduced CCK secretion. Furthermore, both studies have confirmed a negative correlation between PYY increase and ghrelin decrease. The suppression of plasma ghrelin and the increase of plasma $\mathrm{PYY}_{3-36}$ after meal may show the compensatory activation of peripheral signals promoting termination of food ingestion. Therefore, Kojima et al. [111] speculate that a gut-hypothalamic pathway involving peripheral hormonal signals, such as ghrelin and PYY, may be related to the pathophysiology of $\mathrm{BN}$.

2.5. CCK. CCK is a member of the gut-brain family of peptide hormones [190]. CCK is secreted by the gastrointestinal system in response to food intake as well as by specialized neurons in the myenteric plexus and the brain [191]. A rise in circulating concentrations of CCK terminates feeding in rats [192]. I.v. CCK infusion decreases hunger and feeding in humans [193].

CCK is synthesized as a 115 -amino acid prepro-CCK that is cleaved to generate CCK-58. CCK-58 is the largest circulating form of the hormone in humans. From the amino terminus of the peptide, it undergoes sequential proteolytic cleavage generating shorter peptides: CCK-39, CCK-33, CCK22, CCK-12, and CCK-8. CCK-8 is the smallest fragment with complete biological activity [191]. CCK performs its numerous functions by binding to G-coupled CCK receptors located on the targets organs. Two different receptors have been identified: CCK-1 and CCK-2. CCK-1 receptors are abundant in the gut and in a few discrete brain regions (NTS, the area postrema and the hypothalamus), while CCK-2 receptors are expressed in the cerebral cortex, the hypothalamus, vagal nerve, spinal cord, and gastric mucosa [191]. It was confirmed that CCK released from the small intestine when nutrients enter the duodenum stimulates CCK-1 receptor on sensory fibres of vagal afferents that transfer signals to the NTS in the brainstem [194]; both ghrelin and CCK, after release from the gut, transmit starvation and satiety signals to the brain through the GHS-R la and CCK-1 receptors, respectively, located in the vagal afferents. Lesions of the vagus nerve or the NTS abolish the satiety effect of CCK [8]. The satiety hormone CCK activates adrenergic/noradrenergic NTS neurons. Hisadome et al. [195] suggest that epinephrine and NE act as anorectic signals at the level of the NTS. Central administration of CCK also inhibits feeding via the activation of CCK-2 receptors which are expressed in the ventromedial and paraventricular hypothalamic nuclei [196].

Chen et al. [197] showed that CCK-2 receptor knockout mice had increased body weight but smaller AT mass. Only CCK-2 receptors but not CCK-1 receptors are expressed in AT suggesting that CCK-2 receptors regulate fat metabolism and that CCK-2 receptor may play a role in adipose differentiation. However, Clerc et al. [198] reported that hyperphagia and increased fat deposition were observed in CCK-2 receptor deficient mice. Until now, little has been known about the role of CCK-2 receptors in AT.

2.5.1. CCK Levels in AN and BN. Some studies in AN patients have found elevations in basal plasma CCK levels [199, 200] as well as increased CCK release following a test meal in anorectic patients [201] (Table 2). Other studies have found that measures of CCK function in AN were similar to or lower than in control subjects [202-204].

However, BN patients exhibit impaired CCK secretion [188], and levels of CCK in BN are reduced during symptomatic phases of the disorder and also during a phase of initial recovery [205]. Patients with BN have diminished release of CCK following ingestion of a standardized test meal [187, 206] (Table 2). It has been suggested that the decreased CCK response to a meal may play a role in diminished postingestive satiety observed in $\mathrm{BN}$ and that may contribute to the perpetuation and frequent relapse of this disorder [207, 208] (Table 2).

2.6. Leptin. Leptin is a 167 -amino acid protein known to suppress appetite and regulate energy expenditure, and it suppresses activity of NPY neurons and stimulates proopiomelanocortin (POMC)/CART neurons in the arcuate nucleus of the hypothalamus. Leptin is secreted exclusively by adipocytes [209], and leptin has also been found in the stomach [210] and the pituitary gland [211]. Nevertheless, AT remains its main source responsible for $95 \%$ of leptin production [212]. Leptin acts through the leptin receptor (OB$\mathrm{R})$, which is expressed in the hypothalamus and peripheral tissues such as the gut and AT. This ubiquitous distribution of OB-R underlies the pleiotropic roles of leptin [213]. Soluble OB-R represents the major leptin binding activity in human plasma [214]. During nutritional recovery, leptin increases and the OB-R decreases indicating that OB-R could be used as a valid biomarker for nutritional recovery [215].

Plasma leptin levels reflect both energy stores and acute energy balance. Circulating leptin levels are positively correlated with BMI and AT mass, and food restriction results in suppression of plasma leptin levels, which can be reversed by refeeding [16]. Peripheral leptin administration reduces food intake resulting in loss of fat mass [216]. It was suggested that leptin-induced increases in energy expenditure may reflect an activation of the SNS [217]. A report by Tang-Christensen 
et al. [218] support that central leptin administration activates the SNS and that increases plasma NE levels in primates.

Adipocytes possess large numbers of $\mathrm{GH}$ receptors, and it was shown that GH directly regulates leptin gene production [219] and that hyperleptinemia may suppress ghrelin secretion [220]. Furthermore, leptin has been shown to play a stimulatory role in $\mathrm{GH}$ secretion in rats [221]; however, leptin is likely to exert an inhibitory action on GH secretion via a stimulatory effect on hypothalamic somatostatin activity in humans [95], and/or GH hyposecretion might be explained by a resistance to leptin action because hyperleptinemia might contribute to the GH hyposecretion of obese patients [222], and it is suggested that the malnutrition-dependent reduction of leptin levels may play a role in the hypersomatotropism of AN [94, 99, 223].

As shown by recent studies, leptin dose dependently inhibits ghrelin transcription in vitro [224] and decreases ghrelin release from isolated rat stomach [225]. These findings raised the possibility that hyperleptinemia may suppress ghrelin secretion in obese patients [226]. There is also an opposing relation that ghrelin hypersecretion is in conjunction with hypoleptinemia in AN [94]. The importance of leptin as adiposity signal to the brain is revealed by evidence that leptin inhibits the activity of orexigenic ghrelin-NPY network, whereas low plasma leptin levels upregulate the expression of NPY neurons which coexpress ghrelin receptors [220].

Furthermore, the production of leptin is influenced by several regulators, being stimulated by antilipolytic insulin and blood glucose but inhibited by sympathetic activity, lipolytic catecholamines, and FFA [227]. As reported by Frühbeck et al. [228], leptin appears to be involved in the regulation of AT metabolism by both inhibiting lipogenesis [229] and stimulating lipolysis [227].

2.6.1. Plasma, Soluble OB-R, and AT Leptin Levels in AN and $B N$. It was shown that leptin is the major hormone to trigger the adaptation of an organism to food restriction [230]. These findings indicate that the drop in leptin secretion associated with weight loss induced via a reduced energy intake is a major trigger underlying adaptation to starvation in $\mathrm{AN}$ [231]. In malnourished and underweight AN patients, plasma leptin levels are consistently found to be markedly lower than in normal weight controls [29, 30, 161, 179, 231, 232], and weight recovery in $\mathrm{AN}$ is associated with a trend toward, increases in plasma leptin levels $[223,233]$ (Table 2). In contrast, plasma soluble OB-R level was reported to be increased $[232,234]$. This increase may reflect a protective mechanism that decreases free leptin bioavailability and thus further facilitates energy conservation in AN patients [232].

Interestingly, in our study, Dostalova et al. [232] reported significantly reduced plasma leptin levels but normal dialysate leptin concentrations in subcutaneous abdominal AT in AN patients. This finding could be explained by the increased number of smaller adipocytes in subcutaneous abdominal AT leading to a higher number of adipocytes per volume in AN patients when compared with the controls. Another explanation of this may be due to a reduced efficiency of both the SNS [179] and NPY inhibiting adipocyte leptin production in $\mathrm{AN}$. On the other hand, because of reduced volume of subcutaneous abdominal AT, less leptin is secreted into plasma. It has been shown that SNS can exert tonic inhibitory action on leptin secretion and that adrenergic regulation may contribute to rapid decrease both of plasma leptin and insulin levels during exercise in $\mathrm{AN}$ and $\mathrm{BN}$ patients $[6,7,30]$.

Recently, Fazeli et al. [99] have shown that administration of supraphysiological recombinant $\mathrm{GH}$ in patients with $\mathrm{AN}$ leads to significantly decrease in plasma leptin levels when compared with the placebo AN group.

In normal weight subjects with $\mathrm{BN}$, plasma leptin levels have been reported to be either decreased [235, 236] or normal $[234,237]$ (Table 2). It has been reported that BN patients with a significantly higher number of daily binge/vomiting episodes hyposecrete leptin in spite of no changes in their BMI [6, 7, 238, 239]. Interestingly, we observed opposite changes in plasma leptin and ghrelin levels during the exercise with Aci administration and in the postexercise recovering phase in both $\mathrm{BN}$ patients and healthy women $[6,7,12,13,240]$. Plasma soluble OB-R was unaffected in $\mathrm{BN}$ patients when compared with the controls [234].

\section{Conclusions}

In $\mathrm{AN}$, there is a characteristic excess of both feeding stimulatory and feeding inhibitory signalling, producing the "mixed" signals for satiety and desire to feed leading to failure of hypothalamic regulatory pathways [241]. AN may be consistent with a state of nutritionally acquired $\mathrm{GH}$ resistance [99] and with the mechanism of the state of ghrelin resistance in $\mathrm{AN}[48,242]$. The ghrelin autoantibodies could alter the feeding regulatory neurocircuitry and eating behavior by changing of the signalling of the hormone ranging from transport to neutralization resulting in the phenomenon of ghrelin resistance in AN patients [48] (Table 1, Figure 2). Very recently, Acres et al. [243] and Hornig and Lipkin [104] hypothesize that AN is an autoimmune disease and may also be associated with major histocompatibility complex (MHC) gene polymorphisms. Indeed, the development of type 1 diabetes in adolescence seems to place girls at risk for the subsequent development of AN and BN [244, 245]. Thus, autoimmune disorders are associated with increased secretion of leptin, whereas $\mathrm{AN}$ and $\mathrm{BN}$ are conditions of reduced leptin production. Hence, leptin could represent the "missing link" between autoimmunity and nutritional status. Also, $\mathrm{BN}$ is associated with an autoimmunity [43]. In BN patients, decreased levels of autoantibodies against serotonin (IgG class) may be involved with the lack of satiety. Also the decreased levels of autoantibodies against dopamine and dopamine-beta-hydroxylase (IgG, and IgM classes) could be implicated in the exaggerated hunger of bulimic patients [43] (Table 1, Figure 2).

Nevertheless, high ghrelin and low leptin concentrations suggest an orexigenic adaptive mechanism of appetite regulation in response to low food intake in AN $[100,175,231]$ (Tables 1 and 2). Differences between central and peripheral secretion of hypothalamic neuropeptides, gut-related 
peptides, adipocytokines, and the altered cosecretion of hormones with monoamines (NPY-NE; CCK-dopamine; CCKserotonin; PYY-serotonin) were found in AN and BN [21-23, $37-39,41,42]$. Indeed, obesity-prone rats have abnormalities in their dopamine system, a key component of hedonic regulation [246], and acutely ill BN subjects have a reduced striatal dopamine transporter availability as well as reduced hypothalamic serotonin transporter availability [247]. Gut hormones, such as PYY and ghrelin, in humans alter brain activation in these corticolimbic areas and higher cortical regions [248, 249]. Thus, patients with BN mainly had an excess of ghrelin with binge eating behavior and decreased anorexigenic signals by neurotransmodulator disturbances [38, 108, 110, 111, 175, 188]. These "mixed" signals could underlie bulimic binge eating behavior in which a relative increase in orexigenic and a decrease in anorexigenic signalling is characteristic (Tables 1 and 2). Ghrelin secretion in AN is higher in its cephalic phase and may eventually facilitate binge eating behavior in bulimic subjects [250].

Importantly, the mesolimbic reward system including the ventral striatum and ventral regions of the anterior cingulated cortex and of the orbitofrontal cortex has been proposed to play a pivotal role in the genesis of AN [23, 251] (Figure 1). Indeed, a functional magnetic resonance imaging (fMRI) study showed that the central striatal reward system in AN was hyperactivated upon processing of disease-specific stimuli [252]. Thus, changes in peptidergic neurophysiology occurring in the acute state of an eating disorder may play a pivotal role in the pathophysiology of the disorder by providing a possible link between motivated behavior, reward processes, cognitive functions, and energy balance [253, 254]. Although not consistently, hypoactivation of brain areas was documented in the mesolimbic reward system in women with active AN and weight-restored women with AN [255].

Therefore, these observations may contribute to the disruption of AT-gut-brain signalling system and neutralizing autoantibodies in eating disorders (Figures 1 and 2). In recent years, knowledge in the field of food behavior has widely increased, leading to the design of molecules targeted for pharmacological correction of eating disorders and weight control [256]. Also lower dosages of leptin could potentially ameliorate hyperactivity, depression, the metabolic profile, and reproductive function in acutely ill AN patients after weight regain [257]. At present, leptin, ghrelin, GOAT, NPY, tumour necrosis factor-alpha (TNF- $\alpha$ ) downregulating agents such as dexamethasone and potentially Aci, or their synthetic analogs $[6,7,13,56,256-258]$ as well as selective serotonin reuptake inhibitors (SSRI) and serotonin NE reuptake inhibitors (SNRI) may be useful agents for the modulation of food intake, especially serotonin-dopamine antagonists (e.g., Olanzapine) which have been found to be effective for treating $\mathrm{AN}[256,259]$. In the treatment of eating disorders, modified blood-brain barrier in $\mathrm{AN}$ and $\mathrm{BN}$ is a therapeutic target for delivery of any therapeutics to the central nervous system $[103,104,260]$ (Figure 2). The circulating autoantibodies against appetite-regulating neuropeptides and neurotransmitters can be purified and used as monoclonal antibodies in AN and BN. Thus, pharmacologically active monoclonal antibodies would recognize not only the peptide but also the corresponding sequence in the native receptor [261]. Further research is required to investigate the gut-brain-AT orexigenic/anorexigenic agonists or antagonists [262] and the modifications of their pathways with receptors and neutralizing autoantibodies as well as clearance of peptide for potential treatment of eating disorders such as AN and BN in clinical practice [263-265]. Taken together, more data are needed to clarify the etiopathogenesis and pathophysiology of AN and BN. New hopes have arisen through by the recent progress in understanding the immunoneuroendocrine regulation of energy metabolism and feeding behavior because the current long-term pharmacological therapy of anorectic and bulimic patients is almost unsuccessful [266]. Eating disorders and depression are frequently associated. Indeed, an increase of plasma NPY levels may be due to a protective mechanism that prevents the exhaustion of energy reserves in $\mathrm{BN}$ and $\mathrm{AN}$ patients $[6,14]$. Thus, Garcia et al. [267] supported NPY protective role in depression and that decreased plasma levels of NPY autoantibodies (IgG class) are relevant to altered mood while their increased affinities may participate in reduced appetite and body weight in depressive disorder (Table 1, Figure 2). We believe that results of this review may be helpful for better understanding participation of the AT-gut-brain axis peptides and neutralizing autoantibodies on pathophysiology of eating disorders such as $\mathrm{AN}$ and $\mathrm{BN}$.

\section{Abbreviations}

$\begin{array}{ll}\text { AN: } & \text { Anorexia nervosa } \\ \text { BN: } & \text { Bulimia nervosa } \\ \text { AT: } & \text { Adipose tissue } \\ \text { NPY: } & \text { Neuropeptide Y } \\ \text { PYY: } & \text { Peptide YY } \\ \text { PP: } & \text { Pancreatic polypeptide } \\ \text { CCK: } & \text { Cholecystokinin } \\ \text { NE: } & \text { Norepinephrine } \\ \text { GH: } & \text { Growth hormone } \\ \text { GHS: } & \text { Growth hormone secretagogue } \\ \text { GHS-R: } & \text { Growth hormone secretagogue receptor } \\ \text { GHRH: } & \text { Growth-hormone releasing hormone } \\ \text { FGF 21: } & \text { Fibroblast growth factor 21 } \\ \text { FFA: } & \text { Free fatty acids } \\ \text { OB-R: } & \text { Leptin receptor } \\ \text { BMI: } & \text { Body mass index } \\ \text { DPP-IV: } & \text { Dipeptidyl peptidase IV } \\ \text { CRF } 1,2-R: & \text { Corticotropin-releasing factor receptor } \\ & \text { subtype 1, } 2 \\ \text { CART: } & \text { Cocaine- and amphetamine-regulated } \\ \text { GOAT: } & \text { transcript } \\ \text { 3T3-L1: } & \text { Preadipocytes } \\ \text { GPR39: } & \text { G-protein-coupled receptor 39 } \\ \text { GLP-1: } & \text { Glucagon-like peptide-1 } \\ \text { IGF-1: } & \text { Insulin growth factor 1 } \\ \text { SNS: } & \text { Nucleus tractus solitarius } \\ \text { Aci: } & \text { Sympathetic nervous system } \\ \text { Ig: } & \text { Acipimox } \\ & \text { Immunoglobulin } \\ & \end{array}$




$\begin{array}{ll}\text { PPAR- } \alpha: & \begin{array}{l}\text { Peroxisome proliferator-activated } \\ \text { receptor-alpha }\end{array} \\ \text { i.v.: } & \text { Intravenous } \\ \text { SSRI: } & \text { Selective serotonin reuptake inhibitors } \\ \text { SNRI: } & \text { Serotonin norepinephrine reuptake inhibitors } \\ \text { MHC: } & \text { Major histocompatibility complex } \\ \text { TNF- } \alpha: & \text { Tumour necrosis factor-alpha } \\ \alpha \text {-MSH: } & \text { Alpha-melanocyte-stimulating hormone } \\ \text { HOMA-IR: } & \text { Homeostasis model assessment of insulin } \\ & \text { resistance } \\ \text { POMC: } & \text { Proopiomelanocortin } \\ \text { fMRI: } & \text { Functional magnetic resonance imaging } \\ \text { PANDAS: } & \text { Pediatric Autoimmune Neuropsychiatric } \\ & \text { Disorders Associated with Streptococcal } \\ & \text { infection } \\ \text { i.e.: } & \text { In other words. }\end{array}$

\section{Conflict of Interests}

There is no conflict of interests.

\section{Acknowledgments}

This study was supported by Grant no. 303/03/0376 from the Grant Agency GA CR of the Czech Republic. Also, this study was supported by Grant no. NR/9158-3 provided by the IGA Grant Agency of the Ministry of Health, Czech Republic, and by the project of Ministry of Health (Czech Republic) for conceptual development of research organization 00023761 (Institute of Endocrinology, Prague, Czech Republic).

\section{References}

[1] L. K. G. Hsu, "Epidemiology of the eating disorders," Psychiatric Clinics of North America, vol. 19, no. 4, pp. 681-700, 1996.

[2] B. Vitiello and I. Lederhendler, "Research on eating disorders: current status and future prospects," Biological Psychiatry, vol. 47, no. 9, pp. 777-786, 2000.

[3] W. H. Kaye, A. Wagner, J. L. Fudge, and M. Paulus, "Neurocircuity of eating disorders," Current Topics in Behavioral Neurosciences, vol. 6, pp. 37-57, 2011.

[4] DSM-IV-TR: Diagnostic and Statistical Manual of Mental Disorders, American Psychiatric Association, Washington, DC, USA, 4th edition, 2000.

[5] M. M. Meguid, Z.-J. Yang, and J. R. Gleason, "The gut-brain brain-gut axis in anorexia: toward an understanding of food intake regulation," Nutrition, vol. 12, no. 1, pp. S57-S62, 1996.

[6] K. Smitka, H. Papezova, K. Vondra, M. Hill, V. Hainer, and J. Nedvidkova, "A higher response of plasma neuropeptide Y, growth hormone, leptin levels and extracellular glycerol levels in subcutaneous abdominal adipose tissue to Acipimox during exercise in patients with bulimia nervosa: single-blind, randomized, microdialysis study," Nutrition and Metabolism, vol. 8, article 81, 2011.

[7] K. Smitka, H. Papezova, K. Vondra, M. Hill, V. Hainer, and J. Nedvidkova, "Short-term exercise combined with Acipimox administration induces an increase in plasma ACTH levels and its subsequent fall in the recovery phase in bulimic women," Regulatory Peptides, vol. 182, pp. 45-52, 2013.
[8] S. J. Konturek, J. W. Konturek, T. Pawlik, and T. Brzozowski, "Brain-gut axis and its role in the control of food intake," Journal of Physiology and Pharmacology, vol. 55, no. 1, pp. 137-154, 2004.

[9] J. A. Romijn, E. P. Corssmit, L. M. Havekes, and H. Pijl, "Gutbrain axis," Current Opinion in Clinical Nutrition and Metabolic Care, vol. 11, no. 4, pp. 518-521, 2008.

[10] C. L. Roth and T. Reinehr, "Roles of gastrointestinal and adipose tissue peptides in childhood obesity and changes after weight loss due to lifestyle intervention," Archives of Pediatrics and Adolescent Medicine, vol. 164, no. 2, pp. 131-138, 2010.

[11] D. Sedlackova, J. Kopeckova, H. Papezova et al., "Changes of plasma obestatin, ghrelin and NPY in anorexia and bulimia nervosa before and after a high-carbohydrate breakfast," Physiological Research, vol. 60, pp. 165-173, 2011.

[12] K. Smitka, H. Papezova, H. Kvasnickova et al., "Increased response of growth hormone and ghrelin to exercise and antilipolytic drug in bulimia nervosa patients," in Proceedings of the 13th International Congress of Endocrinology, A. GodoyMatos and J. Wass, Eds., pp. 445-449, International Proceedings Division, Medimond Srl, Rio de Janeiro, Brazil, November 2008, http://www.medimond.com/proceedings/moreinfo/20081108 .htm.

[13] J. Nedvidkova, K. Smitka, H. Papezova, K. Vondra, M. Hill, and V. Hainer, "Acipimox during exercise points to an inhibitory feedback of GH on ghrelin secretion in bulimic and healthy women," Regulatory Peptides, vol. 167, no. 1, pp. 134-139, 2011.

[14] D. Sedlackova, J. Kopeckova, H. Papezova et al., "Comparison of high-carbohydrate and high-protein breakfast effect on plasma ghrelin, obestatin, NPY and PYY levels in women with anorexia and bulimia nervosa," Nutrition \& Metabolism, vol. 9, p. 52, 2012.

[15] M. Arosio, C. L. Ronchi, C. Gebbia, V. Cappiello, P. BeckPeccoz, and M. Peracchi, "Stimulatory effects of ghrelin on circulating somatostatin and pancreatic polypeptide levels," Journal of Clinical Endocrinology and Metabolism, vol. 88, no. 2, pp. 701-704, 2003.

[16] S. Stanley, K. Wynne, B. McGowan, and S. Bloom, "Hormonal regulation of food intake," Physiological Reviews, vol. 85, no. 4, pp. 1131-1158, 2005.

[17] J. V. Zhang, P.-G. Ren, O. Avsian-Kretchmer et al., "Obestatin, a peptide encoded by the ghrelin gene, opposes ghrelin's effects on food intake," Science, vol. 310, no. 5750, pp. 996-999, 2005.

[18] A. C. Prince, S. J. Brooks, D. Stahl, and J. Treasure, "Systematic review and meta-analysis of the baseline concentrations and physiologic responses of gut hormones to food in eating disorders," American Journal of Clinical Nutrition, vol. 89, no. 3, pp. 755-765, 2009.

[19] W. H. Kaye, G. K. Frank, U. F. Bailer et al., "Serotonin alterations in anorexia and bulimia nervosa: new insights from imaging studies," Physiology and Behavior, vol. 85, no. 1, pp. 73-81, 2005.

[20] W. H. Kaye, U. F. Bailer, G. K. Frank, A. Wagner, and S. E. Henry, "Brain imaging of serotonin after recovery from anorexia and bulimia nervosa," Physiology and Behavior, vol. 86, no. 1-2, pp. 15-17, 2005.

[21] D. Kontis and E. Theochari, "Dopamine in anorexia nervosa: a systematic review," Behavioural Pharmacology, vol. 23, pp. 496515, 2012.

[22] D. J. Haleem, "Serotonin neurotransmission in anorexia nervosa," Behavioural Pharmacology, vol. 23, pp. 478-495, 2012.

[23] W. H. Kaye, C. E. Wierenga, U. F. Bailer, A. N. Simmons, and A. Bischoff-Grethe, "Nothing tastes as good as skinny feels: the neurobiology of anorexia nervosa," Trends in Neurosciences, vol. 36, pp. 110-120, 2013. 
[24] K. Nonogaki, K. Ohashi-Nozue, and Y. Oka, "A negative feedback system between brain serotonin systems and plasma active ghrelin levels in mice," Biochemical and Biophysical Research Communications, vol. 341, no. 3, pp. 703-707, 2006.

[25] R. L. Bradley, J. P. R. Mansfield, and E. Maratos-Flier, "Neuropeptides, including neuropeptide y and melanocortins, mediate lipolysis in murine adipocytes," Obesity Research, vol. 13, no. 4, pp. 653-661, 2005.

[26] K. H. Schulpis, I. Papassotiriou, M. Vounatsou, G. A. Karikas, S. Tsakiris, and G. P. Chrousos, "Morning preprandial plasma ghrelin and catecholamine concentrations in patients with phenylketonuria and normal controls: evidence for catecholamine-mediated ghrelin regulation," Journal of Clinical Endocrinology and Metabolism, vol. 89, no. 8, pp. 3983-3987, 2004.

[27] J. Nedvídková, K. Smitka, V. Kopský, and V. Hainer, "Adiponectin, an adipocyte-derived protein," Physiological Research, vol. 54, no. 2, pp. 133-140, 2005.

[28] I. Dostálová, K. Smitka, H. Papežová, H. Kvasničková, and J. Nedvídková, "The role of adiponectin in increased insulin sensitivity of patients with anorexia nervosa," Vnitrni Lekarstvi, vol. 52, no. 10, pp. 887-890, 2006.

[29] I. Dostálová, K. Smitka, H. Papežová, H. Kvasničková, and J. Nedvídková, "Increased insulin sensitivity in patients with anorexia nervosa: the role of adipocytokines," Physiological Research, vol. 56, no. 5, pp. 587-594, 2007.

[30] I. Dostalova, V. Bartak, H. Papezova, and J. Nedvidkova, “The effect of short-term exercise on plasma leptin levels in patients with anorexia nervosa," Metabolism, vol. 56, no. 4, pp. 497-503, 2007.

[31] P. Vargovic, J. Ukropec, M. Laukova et al., "Adipocytes as a new source of catecholamine production," FEBS Letters, vol. 585, no. 14, pp. 2279-2284, 2011.

[32] R. Kvetnansky, J. Ukropec, M. Laukova, B. Manz, K. Pacak, and P. Vargovic, "Stress stimulates production of catecholamines in rat adipocytes," Cellular and Molecular Neurobiology, vol. 32, no. 5, pp. 801-813, 2012.

[33] I. Krykorkova, K. Pacak, V. Bartak, H. Papezova, M. Matejkova-Behanova, and J. Nedvidkova, "Increased basal and maprotiline-stimulated norepinephrine levels in abdominal fat in patients with anorexia nervosa," Diabetologie Metabolismus Endokrinologie Výživa, supplement 3, p. 28, 2001.

[34] V. Bartak, J. Nedvidkova, S. Vybiral et al., "Adrenergic regulation of lipolysis in patients with anorexia nervosa during exercise," Physiological Research, vol. 52, p. 24P, 2003.

[35] J. Nedvidkova, I. Dostalova, V. Bartak, H. Papezova, and K. Pacak, "Increased subcutaneous abdominal tissue norepinephrine levels in patients with anorexia nervosa: an in vivo microdialysis study," Physiological Research, vol. 53, pp. 409413, 2004

[36] V. Bartak, S. Vybiral, H. Papezova, I. Dostalova, K. Pacak, and J. Nedvidkova, "Basal and exercise-induced sympathetic nervous activity and lipolysis in adipose tissue of patients with anorexia nervosa," European Journal of Clinical Investigation, vol. 34, no. 5, pp. 371-377, 2004.

[37] F. Brambilla, "Aetiopathogenesis and pathophysiology of bulimia nervosa: biological bases and implications for treatment," CNS Drugs, vol. 15, no. 2, pp. 119-136, 2001.

[38] Y. Takimoto, A. Inui, H. Kumano, and T. Kuboki, "Orexigenic/anorexigenic signals in Bulimia nervosa," Current Molecular Medicine, vol. 3, no. 4, pp. 349-360, 2003.

[39] D. C. Jimerson and B. E. Wolfe, "Neuropeptides in eating disorders," CNS Spectrums, vol. 9, no. 7, pp. 516-522, 2004.
[40] J. A. Harrold, "Hypothalamic control of energy balance," Current Drug Targets, vol. 5, no. 3, pp. 207-219, 2004.

[41] A. Torsello, F. Brambilla, L. Tamiazzo et al., "Central dysregulations in the control of energy homeostasis and endocrine alterations in anorexia and bulimia nervosa," Journal of Endocrinological Investigation, vol. 30, no. 11, pp. 962-976, 2007.

[42] K. Nunn, I. Frampton, and B. Lask, "Anorexia nervosa-a noradrenergic dysregulation hypothesis," Medical Hypotheses, vol. 78, no. 5, pp. 580-584, 2012.

[43] M. Corcos, F. Atger, P. Lévy-Soussan et al., "Bulimia nervosa and autoimmunity," Psychiatry Research, vol. 87, no. 1, pp. 7782, 1999.

[44] S. O. Fetissov, M. Hamze Sinno, Q. Coquerel et al., "Emerging role of autoantibodies against appetite-regulating neuropeptides in eating disorders," Nutrition, vol. 24, no. 9, pp. 854-859, 2008.

[45] S. O. Fetissov, J. Harro, M. Jaanisk et al., "Autoantibodies against neuropeptides are associated with psychological traits in eating disorders," Proceedings of the National Academy of Sciences of the United States of America, vol. 102, no. 41, pp. 14865-14870, 2005.

[46] S. O. Fetissov, "In search of the missing link in the regulation of appetite and body weight," Nutrition, vol. 25, no. 3, pp. 252-254, 2009.

[47] S. O. Fetissov, M. Hamze Sinno, M. Coëffier et al., "Autoantibodies against appetite-regulating peptide hormones and neuropeptides: putative modulation by gut microflora," Nutrition, vol. 24, no. 4, pp. 348-359, 2008.

[48] M. Terashi, A. Asakawa, T. Harada et al., "Ghrelin reactive autoantibodies in restrictive anorexia nervosa," Nutrition, vol. 27, no. 4, pp. 407-413, 2011.

[49] R. P. Radermecker, E. Renard, and A. J. Scheen, "Circulating insulin antibodies: influence of continuous subcutaneous or intraperitoneal insulin infusion, and impact on glucose control," Diabetes/Metabolism Research and Reviews, vol. 25, no. 6, pp. 491-501, 2009.

[50] B. Franke, T. S. Galloway, and T. J. Wilkin, "Developments in the prediction of type 1 diabetes mellitus, with special reference to insulin autoantibodies," Diabetes/Metabolism Research and Reviews, vol. 21, no. 5, pp. 395-415, 2005.

[51] A. Prioletta, G. Muscogiuri, G. P. Sorice et al., "In anorexia nervosa, even a small increase in abdominal fat is responsible for the appearance of insulin resistance," Clinical Endocrinology, vol. 75, no. 2, pp. 202-206, 2011.

[52] H. Ariyasu, K. Takaya, T. Tagami et al., "Stomach is a major source of circulating ghrelin, and feeding state determines plasma ghrelin-like immunoreactivity levels in humans," Journal of Clinical Endocrinology and Metabolism, vol. 86, no. 10, pp. 4753-4758, 2001.

[53] X. Zhu, Y. Cao, K. Voogd, and D. F. Steiner, "On the processing of proghrelin to ghrelin," Journal of Biological Chemistry, vol. 281, pp. 38867-38870, 2006.

[54] M. Kojima, H. Hosoda, Y. Date, M. Nakazato, H. Matsuo, and K. Kangawa, "Ghrelin is a growth-hormone-releasing acylated peptide from stomach," Nature, vol. 402, no. 6762, pp. 656-660, 1999.

[55] J. Yang, M. S. Brown, G. Liang, N. V. Grishin, and J. L. Goldstein, "Identification of the acyltransferase that octanoylates ghrelin, an appetite-stimulating peptide hormone," Cell, vol. 132, no. 3, pp. 387-396, 2008.

[56] T. D. Müller, M. H. Tschöp, I. Jarick et al., "Genetic variation of the ghrelin activator gene ghrelin $\mathrm{O}$-acyltransferase (GOAT) 
is associated with anorexia nervosa," Journal of Psychiatric Research, vol. 45, no. 5, pp. 706-711, 2011.

[57] H. Kirchner, J. A. Gutierrez, P. J. Solenberg et al., "GOAT links dietary lipids with the endocrine control of energy balance," Nature Medicine, vol. 15, pp. 741-745, 2009.

[58] E. Arvat, L. Di Vito, F. Broglio et al., "Preliminary evidence that Ghrelin, the natural GH secretagogue (GHS)-receptor ligand, strongly stimulates GH secretion in humans," Journal of Endocrinological Investigation, vol. 23, no. 8, pp. 493-495, 2000.

[59] Y. Date, N. Murakami, K. Toshinai et al., "The role of the gastric afferent vagal nerve in Ghrelin-induced feeding and growth hormone secretion in rats," Gastroenterology, vol. 123, no. 4, pp. 1120-1128, 2002.

[60] K. Nonogaki, "Ghrelin and feedback systems," Vitamins and Hormones, vol. 77, pp. 149-170, 2007.

[61] A. Asakawa, A. Inui, M. Fujimiya et al., "Stomach regulates energy balance via acylated ghrelin and desacyl ghrelin," Gut, vol. 54, no. 1, pp. 18-24, 2005.

[62] P. Cassoni, M. Papotti, C. Ghè et al., "Identification, characterization, and biological activity of specific receptors for natural (ghrelin) and synthetic growth hormone secretagogues and analogs in human breast carcinomas and cell lines," Journal of Clinical Endocrinology and Metabolism, vol. 86, no. 4, pp. 17381745, 2001.

[63] W. A. Banks, M. Tschöp, S. M. Robinson, and M. L. Heiman, "Extent and direction of ghrelin transport across the bloodbrain barrier is determined by its unique primary structure," Journal of Pharmacology and Experimental Therapeutics, vol. 302, no. 2, pp. 822-827, 2002.

[64] C.-Y. Chen, A. Inui, A. Asakawa et al., "Des-acyl ghrelin acts by CRF type 2 receptors to disrupt fasted stomach motility in conscious rats," Gastroenterology, vol. 129, no. 1, pp. 8-25, 2005.

[65] T. Inhoff, B. Wiedenmann, B. F. Klapp, H. Mönnikes, and P. Kobelt, "Is desacyl ghrelin a modulator of food intake?" Peptides, vol. 30, no. 5, pp. 991-994, 2009.

[66] D. Sedláčková, I. Dostálová, V. Hainer et al., "Simultaneous decrease of plasma obestatin and ghrelin levels after a high-carbohydrate breakfast in healthy women," Physiological Research, vol. 57, no. 1, pp. S29-S37, 2008.

[67] H. Y. Chen, M. E. Trumbauer, A. S. Chen et al., "Orexigenic action of peripheral ghrelin is mediated by neuropeptide $\mathrm{Y}$ and agouti-related protein," Endocrinology, vol. 145, no. 6, pp. 26072612, 2004.

[68] H. Hozumi, K. Yamanouchi, and M. Nishihara, "Involvement of neuropeptide $\mathrm{Y}$ in hyperphagia in human growth hormone transgenic rats," Journal of Veterinary Medical Science, vol. 68, no. 9, pp. 959-965, 2006.

[69] Y. Date, T. Shimbara, S. Koda et al., "Peripheral ghrelin transmits orexigenic signals through the noradrenergic pathway from the hindbrain to the hypothalamus," Cell Metabolism, vol. 4, no. 4, pp. 323-331, 2006.

[70] K. Ogiso, A. Asakawa, H. Amitani, and A. Inui, "Ghrelin and anorexia nervosa: a psychosomatic perspective," Nutrition, vol. 27, no. 10, pp. 988-993, 2011.

[71] K. Takaya, H. Ariyasu, N. Kanamoto et al., "Ghrelin strongly stimulates growth hormone (GH) release in humans," Journal of Clinical Endocrinology and Metabolism, vol. 85, no. 12, pp. 49084911, 2000.

[72] E. T. Vestergaard, R. Dall, K. H. W. Lange, M. Kjaer, J. S. Christiansen, and J. O. L. Jorgensen, "The ghrelin response to exercise before and after growth hormone administration,"
Journal of Clinical Endocrinology and Metabolism, vol. 92, no. 1, pp. 297-303, 2007.

[73] T. Shiiya, M. Nakazato, M. Mizuta et al., "Plasma ghrelin levels in lean and obese humans and the effect of glucose on ghrelin secretion," Journal of Clinical Endocrinology and Metabolism, vol. 87, no. 1, pp. 240-244, 2002.

[74] D. E. Cummings, D. S. Weigle, R. Scott Frayo et al., "Plasma ghrelin levels after diet-induced weight loss or gastric bypass surgery," New England Journal of Medicine, vol. 346, no. 21, pp. 1623-1630, 2002.

[75] M. Nakazato, N. Murakami, Y. Date et al., "A role for ghrelin in the central regulation of feeding," Nature, vol. 409, no. 6817, pp. 194-198, 2001.

[76] A. J. Van Der Lely, "Ghrelin and new metabolic frontiers," Hormone Research, vol. 71, no. 1, pp. 129-133, 2009.

[77] M. Kojima and K. Kangawa, "Ghrelin: structure and function," Physiological Reviews, vol. 85, no. 2, pp. 495-522, 2005.

[78] J. Liu, H. Lin, P. Cheng, X. Hu, and H. Lu, "Effects of ghrelin on the proliferation and differentiation of 3T3-L1 preadipocytes," Journal of Huazhong University of Science and Technology, vol. 29, no. 2, pp. 227-230, 2009.

[79] A. Rodríguez, J. Gómez-Ambrosi, V. Catalán et al., “Acylated and desacyl ghrelin stimulate lipid accumulation in human visceral adipocytes," International Journal of Obesity, vol. 33, pp. 541-552, 2009.

[80] F. Broglio, C. Gottero, F. Prodam et al., "Non-acylated ghrelin counteracts the metabolic but not the neuroendocrine response to acylated ghrelin in humans," Journal of Clinical Endocrinology and Metabolism, vol. 89, no. 6, pp. 3062-3065, 2004.

[81] N. M. Thompson, D. A. S. Gill, R. Davies et al., "Ghrelin and des-octanoyl ghrelin promote adipogenesis directlyin vivo by a mechanism independent of GHS-Rla," Endocrinology, vol. 145, no. 1, pp. 234-242, 2004.

[82] J. J. Tebbe, C. G. Tebbe, S. Mronga, M. Ritter, and M. K. H. Schäfer, "Central neuropeptide Y receptors are involved in 3rd ventricular ghrelin induced alteration of colonic transit time in conscious fed rats," BMC Gastroenterology, vol. 5, article 5, 2005.

[83] K. Kos, A. L. Harte, P. J. O’Hare, S. Kumar, and P. G. McTernan, "Ghrelin and the differential regulation of des-acyl (DSG) and oct-anoyl ghrelin (OTG) in human adipose tissue (AT)," Clinical Endocrinology, vol. 70, no. 3, pp. 383-389, 2009.

[84] M. Misra, K. K. Miller, V. Stewart et al., "Ghrelin and bone metabolism in adolescent girls with anorexia nervosa and healthy adolescents," Journal of Clinical Endocrinology and Metabolism, vol. 90, no. 9, pp. 5082-5087, 2005.

[85] B. Otto, U. Cuntz, E. Fruehauf et al., "Weight gain decreases elevated plasma ghrelin concentrations of patients with anorexia nervosa," European Journal of Endocrinology, vol. 145, no. 5, pp. 669-673, 2001.

[86] B. Otto, M. Tschöp, and U. Cuntz, "Letter to the Editor: similar fasting ghrelin levels in binge eating/purging anorexia nervosa and restrictive anorexia nervosa," Psychoneuroendocrinology, vol. 29, no. 5, pp. 692-693, 2004.

[87] A. Troisi, G. Di Lorenzo, I. Lega et al., "Plasma ghrelin in anorexia, bulimia, and binge-eating disorder: relations with eating patterns and circulating concentrations of cortisol and thyroid hormones," Neuroendocrinology, vol. 81, no. 4, pp. 259266, 2005.

[88] X. Yin, Y. Li, G. Xu, W. An, and W. Zhang, "Ghrelin fluctuation, what determines its production?" Acta Biochimica et Biophysica Sinica, vol. 41, no. 3, pp. 188-197, 2009. 
[89] M. Karczewska-Kupczewska, M. Straczkowski, A. Adamska et al., "Increased suppression of serum ghrelin concentration by hyperinsulinemia in women with anorexia nervosa," European Journal of Endocrinology, vol. 162, no. 2, pp. 235-239, 2010.

[90] M. Janas-Kozik, I. Krupka-Matuszczyk, I. Malinowska-Kolodziej, and J. Lewin-Kowalik, "Total ghrelin plasma level in patients with the restrictive type of anorexia nervosa," Regulatory Peptides, vol. 140, no. 1-2, pp. 43-46, 2007.

[91] J. Nedvidkova, I. Krykorkova, V. Bartak et al., "Loss of mealinduced decrease in plasma ghrelin levels in patients with anorexia nervosa," Journal of Clinical Endocrinology and Metabolism, vol. 88, no. 4, pp. 1678-1682, 2003.

[92] M. Hotta, R. Ohwada, H. Katakami, T. Shibasaki, N. Hizuka, and K. Takano, "Plasma levels of intact and degraded ghrelin and their responses to glucose infusion in anorexia nervosa," Journal of Clinical Endocrinology and Metabolism, vol. 89, no. 11, pp. 5707-5712, 2004.

[93] N. Germain, B. Galusca, D. Grouselle et al., "Ghrelin and obestatin circadian levels differentiate bingeing-purging from restrictive anorexia nervosa," Journal of Clinical Endocrinology and Metabolism, vol. 95, no. 6, pp. 3057-3062, 2010.

[94] M. Scacchi, A. I. Pincelli, and F. Cavagnini, "Nutritional status in the neuroendocrine control of growth hormone secretion: the model of anorexia nervosa," Frontiers in Neuroendocrinology, vol. 24, no. 3, pp. 200-224, 2003.

[95] R. K. Støving, M. Andersen, A. Flyvbjerg et al., "Indirect evidence for decreased hypothalamic somatostatinergic tone in anorexia nervosa," Clinical Endocrinology, vol. 56, no. 3, pp. 391396, 2002.

[96] L. Gianotti, S. Fassino, G. A. Daga et al., "Effects of free fatty acids and acipimox, a lipolysis inhibitor, on the somatotroph responsiveness to ghrh in anorexia nervosa," Clinical Endocrinology, vol. 52, no. 6, pp. 713-720, 2000.

[97] F. Broglio, L. Gianotti, S. Destefanis et al., "The endocrine response to acute ghrelin administration is blunted in patients with anorexia nervosa, a ghrelin hypersecretory state," Clinical Endocrinology, vol. 60, no. 5, pp. 592-599, 2004.

[98] M. Misra and A. Klibanski, "The neuroendocrine basis of anorexia nervosa and its impact on bone metabolism," Neuroendocrinology, vol. 93, no. 2, pp. 65-73, 2011.

[99] P. K. Fazeli, E. A. Lawson, R. Prabhakaran et al., "Effects of recombinant human growth hormone in anorexia nervosa: a randomized, placebo-controlled study," Journal of Clinical Endocrinology and Metabolism, vol. 95, no. 11, pp. 4889-4897, 2010.

[100] T. F. Hasan and H. Hasan, "Anorexia nervosa: a unified neurological perspective," International Journal of Medical Sciences, vol. 8, no. 8, pp. 679-703, 2011.

[101] P. K. Fazeli, M. Misra, M. Goldstein, K. K. Miller, and A. Klibanski, "Fibroblast growth factor-21 may mediate growth hormone resistance in anorexia nervosa," Journal of Clinical Endocrinology and Metabolism, vol. 95, no. 1, pp. 369-374, 2010.

[102] P. Monteleone, R. Carratù, M. Cartenì et al., "Intestinal permeability is decreased in anorexia nervosa," Molecular Psychiatry, vol. 9, no. 1, pp. 76-80, 2004.

[103] Y. Naisberg, I. Modai, and A. Weizman, "Metabolic bioenergy homeostatic disruption: a cause of anorexia nervosa," Medical Hypotheses, vol. 56, no. 4, pp. 454-461, 2001.

[104] M. Hornig and W. I. Lipkin, "Immune-mediated animal models of Tourette syndrome," Neuroscience \& Biobehavioral Reviews, vol. 37, pp. 1120-1138, 2013.
[105] N. Germain, B. Galusca, D. Grouselle et al., "Ghrelin/obestatin ratio in two populations with low bodyweight: constitutional thinness and anorexia nervosa," Psychoneuroendocrinology, vol. 34, no. 3, pp. 413-419, 2009.

[106] Y. Nakai, H. Hosoda, K. Nin et al., "Plasma levels of active form of ghrelin during oral glucose tolerance test in patients with anorexia nervosa," European Journal of Endocrinology, vol. 149, no. 1, pp. R1-R3, 2003.

[107] T. Harada, T. Nakahara, D. Yasuhara et al., "Obestatin, acyl ghrelin, and des-acyl ghrelin responses to an oral glucose tolerance test in the restricting type of anorexia nervosa," Biological Psychiatry, vol. 63, no. 2, pp. 245-247, 2008.

[108] M. Tanaka, T. Naruo, T. Muranaga et al., "Increased fasting plasma ghrelin levels in patients with bulimia nervosa," European Journal of Endocrinology, vol. 146, no. 6, pp. R1-R3, 2002.

[109] M. Tanaka, T. Naruo, N. Nagai et al., "Habitual binge/purge behavior influences circulating ghrelin levels in eating disorders," Journal of Psychiatric Research, vol. 37, no. 1, pp. 17-22, 2003.

[110] P. Monteleone, V. Martiadis, A. E. Rigamonti et al., "Investigation of peptide YY and ghrelin responses to a test meal in bulimia nervosa," Biological Psychiatry, vol. 57, no. 8, pp. 926931, 2005.

[111] S. Kojima, T. Nakahara, N. Nagai et al., "Altered ghrelin and peptide YY responses to meals in bulimia nervosa," Clinical Endocrinology, vol. 62, no. 1, pp. 74-78, 2005.

[112] P. Monteleone, V. Martiadis, M. Fabrazzo, C. Serritella, and M. Maj, "Ghrelin and leptin responses to food ingestion in bulimia nervosa: implications for binge-eating and compensatory behaviours," Psychological Medicine, vol. 33, no. 8, pp. 1387-1394, 2003.

[113] S. Fassino, G. Abbate Daga, V. Mondelli et al., "Hormonal and metabolic responses to acute ghrelin administration in patients with bulimia nervosa," Psychoneuroendocrinology, vol. 30, no. 6, pp. 534-540, 2005.

[114] A. J. Agnew, E. Robinson, C. M. McVicar et al., "The gastrointestinal peptide obestatin induces vascular relaxation via specific activation of endothelium-dependent NO signalling," British Journal of Pharmacology, vol. 166, no. 1, pp. 327-338, 2012.

[115] R. Nogueiras, P. Pfluger, S. Tovar et al., "Effects of obestatin on energy balance and growth hormone secretion in rodents," Endocrinology, vol. 148, no. 1, pp. 21-26, 2007.

[116] H. Zamrazilová, V. Hainer, D. Sedláčková et al., "Plasma obestatin levels in normal weight, obese and anorectic women," Physiological Research, vol. 57, no. 1, pp. S49-S55, 2008.

[117] D. G. Haider, K. Schindler, G. Prager et al., "Serum retinolbinding protein 4 is reduced after weight loss in morbidly obese subjects," Journal of Clinical Endocrinology and Metabolism, vol. 92, no. 3, pp. 1168-1171, 2007.

[118] G. Gourcerol, D. H. St-Pierre, and Y. Taché, "Lack of obestatin effects on food intake: should obestatin be renamed ghrelinassociated peptide (GAP)?" Regulatory Peptides, vol. 141, no. 1-3, pp. 1-7, 2007.

[119] A. Van Dijck, D. Van Dam, V. Vergote et al., "Central administration of obestatin fails to show inhibitory effects on food and water intake in mice," Regulatory Peptides, vol. 156, no. 1-3, pp. 77-82, 2009.

[120] S. S. Qader, R. Håkanson, J. F. Rehfeld, I. Lundquist, and A. Salehi, "Proghrelin-derived peptides influence the secretion of insulin, glucagon, pancreatic polypeptide and somatostatin: 
a study on isolated islets from mouse and rat pancreas," Regulatory Peptides, vol. 146, no. 1-3, pp. 230-237, 2008.

[121] W. K. Samson, M. M. White, C. Price, and A. V. Ferguson, "Obestatin acts in brain to inhibit thirst," American Journal of Physiology. Regulatory Integrative and Comparative Physiology, vol. 292, no. 1, pp. R637-R643, 2007.

[122] J. P. Camiña, J. F. Campos, J. E. Caminos, C. Dieguez, and F. F. Casanueva, "Obestatin-mediated proliferation of human retinal pigment epithelial cells: regulatory mechanisms," Journal of Cellular Physiology, vol. 211, no. 1, pp. 1-9, 2007.

[123] M. Kapica, M. Zabielska, I. Puzio et al., "Obestatin stimulates the secretion of pancreatic juice enzymes through a vagal pathway in anaesthetized rats-preliminary results," Journal of Physiology and Pharmacology, vol. 58, no. 3, pp. 123-130, 2007.

[124] A.-J. Ren, Z.-F. Guo, Y.-K. Wang et al., "Inhibitory effect of obestatin on glucose-induced insulin secretion in rats," Biochemical and Biophysical Research Communications, vol. 369, no. 3, pp. 969-972, 2008.

[125] W. Pan, H. Tu, and A. J. Kastin, "Differential BBB interactions of three ingestive peptides: obestatin, ghrelin, and adiponectin," Peptides, vol. 27, no. 4, pp. 911-916, 2006.

[126] V. Vergote, S. Van Dorpe, K. Peremans, C. Burvenich, and B. De Spiegeleer, "In vitro metabolic stability of obestatin: kinetics and identification of cleavage products," Peptides, vol. 29, no. 10, pp. 1740-1748, 2008.

[127] E. M. Egido, R. Hernández, J. Marco, and R. A. Silvestre, "Effect of obestatin on insulin, glucagon and somatostatin secretion in the perfused rat pancreas," Regulatory Peptides, vol. 152, no. 1-3, pp. 61-66, 2009.

[128] E. Lauwers, B. Landuyt, L. Arckens, L. Schoofs, and W. Luyten, "Obestatin does not activate orphan G protein-coupled receptor GPR39," Biochemical and Biophysical Research Communications, vol. 351, no. 1, pp. 21-25, 2006.

[129] J. V. Zhang, H. Jahr, C.-W. Luo et al., "Obestatin induction of early-response gene expression in gastrointestinal and adipose tissues and the mediatory role of $\mathrm{G}$ protein-coupled receptor, GPR39," Molecular Endocrinology, vol. 22, no. 6, pp. 1464-1475, 2008.

[130] K. L. Egerod, B. Holst, P. S. Petersen et al., "GPR39 splice variants versus antisense gene LYPD1: expression and regulation in gastrointestinal tract, endocrine pancreas, liver, and white adipose tissue," Molecular Endocrinology, vol. 21, no. 7, pp. 16851698, 2007.

[131] V. Catalán, J. Gómez-Ambrosi, F. Rotellar et al., “The obestatin receptor (GPR39) is expressed in human adipose tissue and is down-regulated in obesity-associated type 2 diabetes mellitus," Clinical Endocrinology, vol. 66, no. 4, pp. 598-601, 2007.

[132] X.-Y. Dong, J.-M. He, S.-Q. Tang, H.-Y. Li, Q.-Y. Jiang, and X.-T. Zou, "Is GPR39 the natural receptor of obestatin?" Peptides, vol. 30, no. 2, pp. 431-438, 2009.

[133] R. Granata, F. Settanni, D. Gallo et al., "Obestatin promotes survival of pancreatic $\beta$-cells and human islets and induces expression of genes involved in the regulation of $\beta$-cell mass and function," Diabetes, vol. 57, no. 4, pp. 967-979, 2008.

[134] M. Fujimiya, K. Ataka, A. Asakawa, C.-Y. Chen, I. Kato, and A. Inui, "Regulation of gastroduodenal motility: acyl ghrelin, des-acyl ghrelin and obestatin and hypothalamic peptides," Digestion, vol. 85, no. 2, pp. 90-94, 2012.

[135] P. Monteleone, C. Serritella, V. Martiadis, P. Scognamiglio, and M. Maj, "Plasma obestatin, ghrelin, and ghrelin/obestatin ratio are increased in underweight patients with anorexia nervosa but not in symptomatic patients with bulimia nervosa," Journal of Clinical Endocrinology and Metabolism, vol. 93, no. 11, pp. 44184421, 2008.

[136] T. Nakahara, T. Harada, D. Yasuhara et al., "Plasma obestatin concentrations are negatively correlated with body mass index, insulin resistance index, and plasma leptin concentrations in obesity and anorexia nervosa," Biological Psychiatry, vol. 64, no. 3, pp. 252-255, 2008.

[137] M. Uehara, D. Yasuhara, T. Nakahara et al., "Increase in energy intake leads to a decrease in obestatin in restricting-type of anorexia nervosa," Experimental and Clinical Endocrinology and Diabetes, vol. 119, no. 9, pp. 536-539, 2011.

[138] N. M. Neary, C. J. Small, and S. R. Bloom, "Gut and mind," Gut, vol. 52, no. 7, pp. 918-921, 2003.

[139] A. Sahu and S. P. Kalra, "Neuropeptidergic regulation of feeding behavior: neuropeptide Y," Trends in Endocrinology and Metabolism, vol. 4, no. 7, pp. 217-224, 1993.

[140] K. Wynne, S. Stanley, B. McGowan, and S. R. Bloom, "Appetite control," Journal of Endocrinology, vol. 184, no. 2, pp. 291-318, 2005.

[141] L. C. Turtzo and M. D. Lane, "NPY and neuron-adipocyte interactions in the regulation of metabolism," EXS, no. 95, pp. 133-141, 2006.

[142] L. C. Turtzo, R. Marx, and M. Daniel Lane, "Cross-talk between sympathetic neurons and adipocytes in coculture," Proceedings of the National Academy of Sciences of the United States of America, vol. 98, no. 22, pp. 12385-12390, 2001.

[143] R. Nogueiras, L. M. Williams, and C. Dieguez, "Ghrelin: new molecular pathways modulating appetite and adiposity," Obesity Facts, vol. 3, no. 5, pp. 285-292, 2010.

[144] V. Coiro, R. Volpi, S. Cataldo et al., "Somatostatin reduces neuropeptide Y rise induced by physical exercise," Hormone and Metabolic Research, vol. 43, no. 5, pp. 361-363, 2011.

[145] V. Coiro, A. Casti, E. Volta et al., "Effect of physical training on reduction of circulating neuropeptide Y levels in elderly humans," Journal of Endocrinological Investigation, vol. 33, no. 2, pp. 132-133, 2010.

[146] I. A. Antonijevic, H. Murck, S. Bohlhalter, R.-M. Frieboes, F. Holsboer, and A. Steiger, "Neuropeptide Y promotes sleep and inhibits ACTH and cortisol release in young men," Neuropharmacology, vol. 39, no. 8, pp. 1474-1481, 2000.

[147] H. Watanobe and T. Tamura, "Stimulation by neuropeptide $\mathrm{Y}$ of growth hormone secretion in prolactinoma in vivo," Neuropeptides, vol. 30, no. 5, pp. 429-432, 1996.

[148] H. Watanobe and T. Tamura, "Stimulatory and inhibitory effects of neuropeptide $\mathrm{Y}$ on growth hormone secretion in acromegaly in vivo," Neuropeptides, vol. 31, no. 1, pp. 29-34, 1997.

[149] J. Pihlajamäki, P. Karhapää, I. Vauhkonen et al., “The Leu7Pro polymorphism of the neuropeptide $\mathrm{Y}$ gene regulates free fatty acid metabolism," Metabolism, vol. 52, no. 5, pp. 643-646, 2003.

[150] C. J. Billington, J. E. Briggs, M. Grace, and A. S. Levine, "Effects of intracerebroventricular injection of neuropeptide $\mathrm{Y}$ on energy metabolism," American Journal of Physiology. Regulatory Integrative and Comparative Physiology, vol. 260, no. 2, pp. R321-R327, 1991.

[151] K. Kos, A. L. Harte, S. James et al., "Secretion of neuropeptide Y in human adipose tissue and its role in maintenance of adipose tissue mass," American Journal of Physiology. Endocrinology and Metabolism, vol. 293, no. 5, pp. E1335-E1340, 2007.

[152] K. Yang, H. Guan, E. Arany, D. J. Hill, and X. Cao, "Neuropeptide $\mathrm{Y}$ is produced in visceral adipose tissue and promotes 
proliferation of adipocyte precursor cells via the Y1 receptor," FASEB Journal, vol. 22, no. 7, pp. 2452-2464, 2008.

[153] K. Kos, A. R. Baker, M. Jernas et al., "DPP-IV inhibition enhances the antilipolytic action of NPY in human adipose tissue," Diabetes, Obesity and Metabolism, vol. 11, no. 4, pp. 285292, 2009.

[154] L. E. Kuo, M. Czarnecka, J. B. Kitlinska, J. U. Tilan, R. Kvetňanský, and Z. Zukowska, "Chronic stress, combined with a high-fat/high-sugar diet, shifts sympathetic signaling toward neuropeptide $\mathrm{Y}$ and leads to obesity and the metabolic syndrome," Annals of the New York Academy of Sciences, vol. 1148, pp. 232-237, 2008.

[155] K. Eaton, F. R. Sallee, and R. Sah, "Relevance of neuropeptide Y (NPY) in psychiatry," Current Topics in Medicinal Chemistry, vol. 7, no. 17, pp. 1645-1659, 2007.

[156] T. R. Gruninger, B. LeBoeuf, Y. Liu, and L. R. Garcia, "Molecular signaling involved in regulating feeding and other motivated behaviors," Molecular Neurobiology, vol. 35, no. 1, pp. 1-19, 2007.

[157] T. Hökfelt, D. Stanic, S. D. Sanford et al., "NPY and its involvement in axon guidance, neurogenesis, and feeding," Nutrition, vol. 24, no. 9, pp. 860-868, 2008.

[158] S. L. Hargrave and K. P. Kinzig, "Repeated gastric distension alters food intake and neuroendocrine profiles in rats," Physiology and Behavior, vol. 105, no. 4, pp. 975-981, 2012.

[159] B. Baranowska, E. Wasilewska-Dziubińska, M. Radzikowska, A. Płonowski, and K. Roguski, "Neuropeptide Y, galanin, and leptin release in obese women and in women with anorexia nervosa," Metabolism, vol. 46, no. 12, pp. 1384-1389, 1997.

[160] J. Nedvídková, H. Papezová, M. Haluzík, and V. Schreiber, "Interaction between serum leptin levels and hypothalamohypophyseal-thyroid axis in patients with anorexia nervosa," Endocrine Research, vol. 26, no. 2, pp. 219-230, 2000.

[161] B. Baranowska, E. Wolinska-Witort, E. Wasilewska-Dziubinska, K. Roguski, and M. Chmielowska, "Plasma leptin, neuropeptide $\mathrm{Y}(\mathrm{NPY})$ and galanin concentrations in bulimia nervosa and in anorexia nervosa," Neuroendocrinology Letters, vol. 22, no. 5, pp. 356-358, 2001.

[162] J. Oświecimska, K. Ziora, G. Geisler, and K. Broll-Waśka, "Prospective evaluation of leptin and neuropeptide Y (NPY) serum levels in girls with anorexia nervosa," Neuroendocrinology Letters, vol. 26, no. 4, pp. 301-304, 2005.

[163] F. Sederholm, A. A. Ammar, and P. Södersten, "Intake inhibition by NPY: role of appetitive ingestive behavior and aversion," Physiology and Behavior, vol. 75, no. 4, pp. 567-575, 2002.

[164] A. A. Ammar, R. Nergårdh, B. B. Fredholm, U. Brodin, and P. Södersten, "Intake inhibition by NPY and CCK-8: a challenge of the notion of NPY as an "Orexigen'”, Behavioural Brain Research, vol. 161, no. 1, pp. 82-87, 2005.

[165] R. Nergårdh, A. Ammar, U. Brodin, J. Bergström, A. Scheurink, and P. Södersten, "Neuropeptide Y facilitates activity-basedanorexia," Psychoneuroendocrinology, vol. 32, no. 5, pp. 493-502, 2007.

[166] U. Pedersen-Bjergaard, U. Høst, H. Kelbæk et al., "Influence of meal composition on postprandial peripheral plasma concentrations of vasoactive peptides in man," Scandinavian Journal of Clinical and Laboratory Investigation, vol. 56, no. 6, pp. 497-503, 1996.

[167] N. Nonaka, S. Shioda, M. L. Niehoff, and W. A. Banks, "Characterization of blood-brain barrier permeability to $\mathrm{PYY}_{3-36}$ in the mouse," Journal of Pharmacology and Experimental Therapeutics, vol. 306, no. 3, pp. 948-953, 2003.
[168] R. L. Batterham, M. A. Cowley, C. J. Small et al., "Gut hormone $\mathrm{PYY}_{3-36}$ physiologically inhibits food intake," Nature, vol. 418, no. 6898, pp. 650-654, 2002.

[169] L. Brunetti, G. Orlando, C. Ferrante, A. Chiavaroli, and M. Vacca, "Peptide YY (3-36) inhibits dopamine and norepinephrine release in the hypothalamus," European Journal of Pharmacology, vol. 519, no. 1-2, pp. 48-51, 2005.

[170] E. S. Corp, J. McQuade, S. Krasnicki, and D. B. Conze, "Feeding after fourth ventricular administration of neuropeptide $Y$ receptor agonists in rats," Peptides, vol. 22, no. 3, pp. 493-499, 2001.

[171] M. R. Druce, C. J. Small, and S. R. Bloom, "Minireview: gut peptides regulating satiety," Endocrinology, vol. 145, no. 6, pp. 2660-2665, 2004.

[172] L. Degen, S. Oesch, M. Casanova et al., "Effect of peptide YY $Y_{3-36}$ on food intake in humans," Gastroenterology, vol. 129, no. 5, pp. 1430-1436, 2005.

[173] R. K. Harding and T. J. McDonald, "Identification and characterization of the emetic effects of peptide YY," Peptides, vol. 10, no. 1, pp. 21-24, 1989.

[174] R. L. Batterham, M. A. Cohen, S. M. Ellis et al., "Inhibition of food intake in obese subjects by peptide $\mathrm{YY}_{3-36}$," New England Journal of Medicine, vol. 349, no. 10, pp. 941-948, 2003.

[175] J. Tong and D. D’Alessio, "Eating disorders and gastrointestinal peptides," Current Opinion in Endocrinology, Diabetes and Obesity, vol. 18, pp. 42-49, 2011.

[176] S.-Y. Ueda, T. Yoshikawa, Y. Katsura, T. Usui, and S. Fujimoto, "Comparable effects of moderate intensity exercise on changes in anorectic gut hormone levels and energy intake to high intensity exercise," Journal of Endocrinology, vol. 203, no. 3, pp. 357-364, 2009.

[177] A. D. Nguyen, H. Herzog, and A. Sainsbury, "Neuropeptide Y and peptide YY: important regulators of energy metabolism," Current Opinion in Endocrinology, Diabetes and Obesity, vol. 18, no. 1, pp. 56-60, 2011.

[178] M. Labelle, Y. Boulanger, A. Fournier, S. St.-Pierre, and R. Savard, "Tissue-specific regulation of fat cell lipolysis by NPY in 6-OHDA-treated rats," Peptides, vol. 18, no. 6, pp. 801-808, 1997.

[179] P. Monteleone, E. Castaldo, and M. Maj, "Neuroendocrine dysregulation of food intake in eating disorders," Regulatory Peptides, vol. 149, no. 1-3, pp. 39-50, 2008.

[180] S. Stock, P. Leichner, A. C. K. Wong et al., "Ghrelin, peptide YY, glucose-dependent insulinotropic polypeptide, and hunger responses to a mixed meal in anorexic, obese, and control female adolescents," Journal of Clinical Endocrinology and Metabolism, vol. 90, no. 4, pp. 2161-2168, 2005.

[181] M. Misra, K. K. Miller, P. Tsai et al., "Elevated peptide YY levels in adolescent girls with anorexia nervosa," Journal of Clinical Endocrinology and Metabolism, vol. 91, no. 3, pp. 1027-1033, 2006.

[182] T. Nakahara, S. Kojima, M. Tanaka et al., "Incomplete restoration of the secretion of ghrelin and PYY compared to insulin after food ingestion following weight gain in anorexia nervosa," Journal of Psychiatric Research, vol. 41, no. 10, pp. 814-820, 2007.

[183] E. A. Lawson, K. T. Eddy, D. Donoho et al., "Appetite-regulating hormones cortisol and peptide YY are associated with disordered eating psychopathology, independent of body mass index," European Journal of Endocrinology, vol. 164, no. 2, pp. 253-261, 2011. 
[184] N. Germain, B. Galusca, C. W. Le Roux et al., "Constitutional thinness and lean anorexia nervosa display opposite concentrations of peptide YY, glucagon-like peptide 1, ghrelin, and leptin," American Journal of Clinical Nutrition, vol. 85, no. 4, pp. 967971, 2007.

[185] W. H. Kaye, W. Berrettini, H. Gwirtsman, and D. T. George, "Altered cerebrospinal fluid neuropeptide Y and peptide YY immunoreactivity in anorexia and bulimia nervosa," Archives of General Psychiatry, vol. 47, no. 6, pp. 548-556, 1990.

[186] K. A. Gendall, W. H. Kaye, M. Altemus, C. W. McConaha, and M. C. La Via, "Leptin, neuropeptide Y, and peptide YY in longterm recovered eating disorder patients," Biological Psychiatry, vol. 46, no. 2, pp. 292-299, 1999.

[187] M. J. Devlin, H. R. Kissileff, E. J. Zimmerli et al., "Gastric emptying and symptoms of bulimia nervosa: effect of a prokinetic agent," Physiology and Behavior, vol. 106, no. 2, pp. 238-242, 2012.

[188] T. D. Geracioti Jr. and R. A. Liddle, "Impaired cholecystokinin secretion in bulimia nervosa," New England Journal of Medicine, vol. 319, no. 11, pp. 683-688, 1988.

[189] H. C. Lin, W. Y. Chey, and X.-T. Zhao, "Release of distal gut peptide YY (PYY) by fat in proximal gut depends on CCK," Peptides, vol. 21, no. 10, pp. 1561-1563, 2000.

[190] G. J. Dockray, "Cholecystokinin and gut-brain signalling," Regulatory Peptides, vol. 155, no. 1-3, pp. 6-10, 2009.

[191] R. Chandra and R. A. Liddle, "Cholecystokinin," Current Opinion in Endocrinology, Diabetes and Obesity, vol. 14, no. 1, pp. 63-67, 2007.

[192] J. Gibbs, R. C. Young, and G. P. Smith, "Cholecystokinin decreases food intake in rats," Journal of Comparative and Physiological Psychology, vol. 84, no. 3, pp. 488-495, 1973.

[193] L. Degen, D. Matzinger, J. Drewe, and C. Beglinger, "The effect of cholecystokinin in controlling appetite and food intake in humans," Peptides, vol. 22, no. 8, pp. 1265-1269, 2001.

[194] S. C. Woods, "Gastrointestinal Satiety Signals. I. An overview of gastrointestinal signals that influence food intake," American Journal of Physiology. Gastrointestinal and Liver Physiology, vol. 286, no. 1, pp. G7-G13, 2004.

[195] K. Hisadome, F. Reimann, F. M. Gribble, and S. Trapp, "CCK stimulation of GLP-1 neurons involves $\alpha 1$-adrenoceptormediated increase in glutamatergic synaptic inputs," Diabetes, vol. 60, no. 11, pp. 2701-2709, 2011.

[196] C. T. Dourish, W. Rycroft, and S. D. Iversen, "Postponement of satiety by blockade of brain cholecystokinin (CCK-B) receptors," Science, vol. 245, no. 4925, pp. 1509-1511, 1989.

[197] H. Chen, S. Kent, and M. J. Morris, "Is the CCK2 receptor essential for normal regulation of body weight and adiposity?" European Journal of Neuroscience, vol. 24, no. 5, pp. 1427-1433, 2006.

[198] P. Clerc, M. G. C. Constans, H. Lulka et al., "Involvement of cholecystokinin 2 receptor in food intake regulation: hyperphagia and increased fat deposition in cholecystokinin 2 receptordeficient mice," Endocrinology, vol. 148, no. 3, pp. 1039-1049, 2007.

[199] E. Philipp, K.-M. Pirke, M. B. Kellner, and J.-C. Krieg, "Disturbed cholecystokinin secretion in patients with eating disorders," Life Sciences, vol. 48, no. 25, pp. 2443-2450, 1991.

[200] H. Tamai, J. Takemura, N. Kobayashi, S. Matsubayashi, S. Matsukura, and T. Nakagawa, "Changes in plasma cholecystokinin concentrations after oral glucose tolerance test in anorexia nervosa before and after therapy," Metabolism, vol. 42, no. 5, pp. 581-584, 1993.
[201] R. F. Harty, P. H. Pearson, T. E. Solomon, and J. E. McGuigan, "Cholecystokinin, vasoactive intestinal peptide and peptide histidine methionine responses to feeding in anorexia nervosa," Regulatory Peptides, vol. 36, no. 1, pp. 141-150, 1991.

[202] F. Brambilla, M. Brunetta, A. Peirone et al., "T-lymphocyte cholecystokinin- 8 and beta-endorphin concentrations in eating disorders: I. Anorexia nervosa," Psychiatry Research, vol. 59, no. 1-2, pp. 43-50, 1995.

[203] B. Baranowska, M. Radzikowska, E. Wasilewska-Dziubinska, K. Roguski, and M. Borowiec, "Disturbed release of gastrointestinal peptides in anorexia nervosa and in obesity," Diabetes, Obesity and Metabolism, vol. 2, no. 2, pp. 99-103, 2000.

[204] U. Cuntz, P. Enck, E. Frühauf et al., "Cholecystokinin revisited: CCK and the hunger trap in anorexia nervosa," PLOS ONE, vol. 8, Article ID e54457, 2013.

[205] R. B. Lydiard, T. D. Brewerton, M. D. Fossey et al., "CSF cholecystokinin octapeptide in patients with bulimia nervosa and in normal comparison subjects," American Journal of Psychiatry, vol. 150, no. 7, pp. 1099-1101, 1993.

[206] M. J. Devlin, B. T. Walsh, J. L. Guss, H. R. Kissileff, R. A. Liddle, and E. Petkova, "Postprandial cholecystokinin release and gastric emptying in patients with bulimia nervosa," American Journal of Clinical Nutrition, vol. 65, no. 1, pp. 114-120, 1997.

[207] U. F. Bailer and W. H. Kaye, "A review of neuropeptide and neuroendocrine dysregulation in anorexia and bulimia nervosa," Current Drug Targets. CNS and Neurological Disorders, vol. 2, no. 1, pp. 53-59, 2003.

[208] S. Hannon-Engel, "Regulating satiety in bulimia nervosa: the role of cholecystokinin," Perspectives in Psychiatric Care, vol. 48, no. 1, pp. 34-40, 2012.

[209] Y. Zhang, R. Proenca, M. Maffei, M. Barone, L. Leopold, and J. M. Friedman, "Positional cloning of the mouse obese gene and its human homologue," Nature, vol. 372, pp. 425-432, 1994.

[210] A. Bado, S. Levasseur, S. Attoub et al., "The stomach is a source of leptin," Nature, vol. 394, no. 6695, pp. 790-793, 1998.

[211] L. Jin, B. G. Burguera, M. E. Couce et al., "Leptin and leptin receptor expression in normal and neoplastic human pituitary: evidence of a regulatory role for leptin on pituitary cell proliferation," Journal of Clinical Endocrinology and Metabolism, vol. 84, no. 8, pp. 2903-2911, 1999.

[212] K. N. Frayn, F. Karpe, B. A. Fielding, I. A. Macdonald, and S. W. Coppack, "Integrative physiology of human adipose tissue," International Journal of Obesity, vol. 27, no. 8, pp. 875-888, 2003.

[213] V. Anubhuti and S. Arora, "Leptin and its metabolic interactions-an update," Diabetes, Obesity and Metabolism, vol. 10, no. 11, pp. 973-993, 2008.

[214] A. Lammert, W. Kiess, A. Bottner, A. Glasow, and J. Kratzsch, "Soluble leptin receptor represents the main leptin binding activity in human blood," Biochemical and Biophysical Research Communications, vol. 283, no. 4, pp. 982-988, 2001.

[215] K. Stein, E. Vasquez-Garibay, J. Kratzsch, E. Romero-Velarde, and G. Jahreis, "Influence of nutritional recovery on the leptin axis in severely malnourished children," Journal of Clinical Endocrinology and Metabolism, vol. 91, no. 3, pp. 1021-1026, 2006.

[216] J. L. Halaas, K. S. Gajiwala, M. Maffei et al., "Weight-reducing effects of the plasma protein encoded by the obese gene," Science, vol. 269, no. 5223, pp. 543-546, 1995.

[217] W. G. Haynes, D. A. Morgan, S. A. Walsh, A. L. Mark, and W. I. Sivitz, "Receptor-mediated regional sympathetic nerve activation by leptin," Journal of Clinical Investigation, vol. 100, no. 2, pp. 270-278, 1997. 
[218] M. Tang-Christensen, P. J. Havel, R. R. Jacobs, P. J. Larsen, and J. L. Cameron, "Central administration of leptin inhibits food intake and activates the sympathetic nervous system in rhesus macaques," Journal of Clinical Endocrinology and Metabolism, vol. 84, no. 2, pp. 711-717, 1999.

[219] C. A. Lissett, P. E. Clayton, and S. M. Shalet, "The acute leptin response to GH," Journal of Clinical Endocrinology and Metabolism, vol. 86, no. 9, pp. 4412-4415, 2001.

[220] S. P. Kalra, N. Ueno, and P. S. Kalra, "Stimulation of appetite by ghrelin is regulated by leptin restraint: peripheral and central sites of action," Journal of Nutrition, vol. 135, no. 5, pp. 1331-1335, 2005.

[221] E. Carro, L. M. Seoane, R. Señaris, R. V. Considine, F. F. Casanueva, and C. Dieguez, "Interaction between leptin and neuropeptide Y on in vivo growth hormone secretion," Neuroendocrinology, vol. 68, no. 3, pp. 187-191, 1998.

[222] C. Dieguez, E. Carro, L. M. Seoane et al., "Regulation of somatotroph cell function by the adipose tissue," International Journal of Obesity, vol. 24, no. 2, pp. S100-S103, 2000.

[223] M. Misra, K. K. Miller, K. Kuo et al., "Secretory dynamics of leptin in adolescent girls with anorexia nervosa and healthy adolescents," American Journal of Physiology. Endocrinology and Metabolism, vol. 289, no. 3, pp. E373-E381, 2005.

[224] Z. Zhao, I. Sakata, Y. Okubo, K. Koike, K. Kangawa, and T. Sakai, "Gastric leptin, but not estrogen and somatostatin, contributes to the elevation of ghrelin mRNA expression level in fasted rats," Journal of Endocrinology, vol. 196, no. 3, pp. 529-538, 2008.

[225] J. Kamegai, H. Tamura, T. Shimizu, S. Ishii, H. Sugihara, and S. Oikawa, "Effects of insulin, leptin, and glucagon on ghrelin secretion from isolated perfused rat stomach," Regulatory Peptides, vol. 119, no. 1-2, pp. 77-81, 2004.

[226] M. Tschöp, C. Weyer, P. A. Tataranni, V. Devanarayan, E. Ravussin, and M. L. Heiman, "Circulating ghrelin levels are decreased in human obesity," Diabetes, vol. 50, no. 4, pp. 707709, 2001.

[227] G. Frühbeck, M. Aguado, and J. A. Martinez, "In vitro lipolytic effect of leptin on mouse adipocytes: evidence for a possible autocrine/paracrine role of leptin," Biochemical and Biophysical Research Communications, vol. 240, no. 3, pp. 590-594, 1997.

[228] G. Frühbeck, S. A. Jebb, and A. M. Prentice, "Leptin: physiology and pathophysiology," Clinical Physiology, vol. 18, no. 5, pp. 399419, 1998.

[229] Y. Bai, S. Zhang, K.-S. Kim, J.-K. Lee, and K.-H. Kim, “Obese gene expression alters the ability of 30A5 preadipocytes to respond to lipogenic hormones," Journal of Biological Chemistry, vol. 271, no. 24, pp. 13939-13942, 1996.

[230] R. S. Ahima, D. Prabakaran, C. Mantzoros et al., "Role of leptin in the neuroendocrine response to fasting," Nature, vol. 382, no. 6588, pp. 250-252, 1996.

[231] K. Holtkamp, B. Herpertz-Dahlmann, C. Mika et al., "Elevated physical activity and low leptin levels co-occur in patients with anorexia nervosa," Journal of Clinical Endocrinology and Metabolism, vol. 88, no. 11, pp. 5169-5174, 2003.

[232] I. Dostalova, V. Kopsky, J. Duskova, H. Papezová, K. Pacak, and J. Nedvidkova, "Leptin concentrations in the abdominal subcutaneous adipose tissue of patients with anorexia nervosa assessed by in vivo microdialysis," Regulatory Peptides, vol. 128, pp. 63-68, 2005.

[233] F. D. Zepf, I. Sungurtekin, F. Glass et al., "Differences in zinc status and the leptin axis in anorexic and recovered adolescents and young adults: a pilot study," Food and Nutrition Research, vol. 56, no. 1, pp. 1-8, 2012.
[234] J. Housova, K. Anderlova, J. Krizová et al., "Serum adiponectin and resistin concentrations in patients with restrictive and binge/purge form of anorexia nervosa and bulimia nervosa," Journal of Clinical Endocrinology and Metabolism, vol. 90, no. 3, pp. 1366-1370, 2005.

[235] P. Monteleone, F. Bortolotti, M. Fabrazzo, A. La Rocca, A. Fuschino, and M. Maj, "Plasma leptin response to acute fasting and refeeding in untreated women with bulimia nervosa," Journal of Clinical Endocrinology and Metabolism, vol. 85, no. 7, pp. 2499-2503, 2000.

[236] T. D. Brewerton, M. D. Lesem, A. Kennedy, and W. T. Garvey, "Reduced plasma leptin concentrations in bulimia nervosa," Psychoneuroendocrinology, vol. 25, no. 7, pp. 649-658, 2000.

[237] S. Zipfel, T. Specht, W. F. Blum et al., "Leptin-a parameter for body fat measurement in patients with eating disorders," European Eating Disorders Review, vol. 6, pp. 38-47, 1998.

[238] D. C. Jimerson, C. Mantzoros, B. E. Wolfe, and E. D. Metzger, "Decreased serum leptin in bulimia nervosa," Journal of Clinical Endocrinology and Metabolism, vol. 85, no. 12, pp. 4511-4514, 2000.

[239] P. Monteleone, V. Martiadis, B. Colurcio, and M. Maj, "Leptin secretion is related to chronicity and severity of the illness in bulimia nervosa," Psychosomatic Medicine, vol. 64, no. 6, pp. 874-879, 2002.

[240] E. T. Vestergaard, T. K. Hansen, S. Nielsen, N. Moller, J. S. Christiansen, and J. O. L. Jorgensen, "Effects of GH replacement therapy in adults on serum levels of leptin and ghrelin: the role of lipolysis," European Journal of Endocrinology, vol. 153, no. 4, pp. 545-549, 2005.

[241] A. Inui, "Eating behavior in anorexia nervosa-an excess of both orexigenic and anorexigenic signalling?" Molecular Psychiatry, vol. 6, no. 6, pp. 620-624, 2001.

[242] K. K. Miller, "Endocrine dysregulation in anorexia nervosa update," Journal of Clinical Endocrinology and Metabolism, vol. 96, no. 10, pp. 2939-2949, 2011.

[243] M. J. Acres, J. J. Heath, and J. A. Morris, "Anorexia nervosa, autoimmunity and the hygiene hypothesis," Medical Hypotheses, vol. 78, no. 6, pp. 772-775, 2012.

[244] M. Takii, Y. Uchigata, J. Kishimoto et al., "The relationship between the age of onset of type 1 diabetes and the subsequent development of a severe eating disorder by female patients," Pediatric Diabetes, vol. 12, no. 4, pp. 396-401, 2011.

[245] L. Prasad-Reddy, "Disordered eating in type 1 diabetes: insulin omission and diabulimia," U.S. Pharmacist, vol. 37, pp. 1-8, 2012.

[246] B. M. Geiger, G. G. Behr, L. E. Frank et al., "Evidence for defective mesolimbic dopamine exocytosis in obesity-prone rats," FASEB Journal, vol. 22, no. 8, pp. 2740-2746, 2008.

[247] F. Van den Eynde and J. Treasure, "Neuroimaging in eating disorders and obesity: implications for research," Child and Adolescent Psychiatric Clinics of North America, vol. 18, no. 1, pp. 95-115, 2009.

[248] R. L. Batterham, D. H. Ffytche, J. M. Rosenthal et al., "PYY modulation of cortical and hypothalamic brain areas predicts feeding behaviour in humans," Nature, vol. 450, no. 7166, pp. 106-109, 2007.

[249] S. Malik, F. McGlone, D. Bedrossian, and A. Dagher, "Ghrelin modulates brain activity in areas that control appetitive behavior," Cell Metabolism, vol. 7, no. 5, pp. 400-409, 2008.

[250] P. Monteleone, C. Serritella, V. Martiadis, and M. Maj, "Deranged secretion of ghrelin and obestatin in the cephalic phase of vagal stimulation in women with anorexia nervosa," Biological Psychiatry, vol. 64, no. 11, pp. 1005-1008, 2008. 
[251] W. H. Kaye, J. L. Fudge, and M. Paulus, "New insights into symptoms and neurocircuit function of anorexia nervosa," Nature Reviews Neuroscience, vol. 10, no. 8, pp. 573-584, 2009.

[252] A.-K. Fladung, G. Grön, K. Grammer et al., "A neural signature of anorexia nervosa in the ventral striatal reward system," American Journal of Psychiatry, vol. 167, no. 2, pp. 206-212, 2010.

[253] P. Monteleone, "New frontiers in endocrinology of eating disorders," Current Topics in Behavioral Neurosciences, vol. 6, pp. 189-208, 2011.

[254] P. Monteleone and M. Maj, "Dysfunctions of leptin, ghrelin, BDNF and endocannabinoids in eating disorders: beyond the homeostatic control of food intake," Psychoneuroendocrinology, vol. 38, pp. 312-330, 2013.

[255] L. M. Holsen, E. A. Lawson, J. Blum et al., "Food motivation circuitry hypoactivation related to hedonic and nonhedonic aspects of hunger and satiety in women with active anorexia nervosa and weight-restored women with anorexia nervosa," Journal of Psychiatry \& Neuroscience, vol. 37, pp. 322-332, 2012.

[256] A. Capasso, C. Petrella, and W. Milano, "Recent clinical aspects of eating disorders," Reviews on Recent Clinical Trials, vol. 4, no. 1, pp. 63-69, 2009.

[257] J. Hebebrand and Ö. Albayrak, "Leptin treatment of patients with anorexia nervosa? The urgent need for initiation of clinical studies," European Child and Adolescent Psychiatry, vol. 21, no. 2, pp. 63-66, 2012.

[258] R. Bou Khalil, O. de Muylder, and F. L. Hebborn, "Treatment of anorexia nervosa with TNF- $\alpha$ down-regulating agents," Eating and Weight Disorders, vol. 16, Article ID e300, 2011.

[259] H. Bissada, G. A. Tasca, A. M. Barber, and J. Bradwejn, "Olanzapine in the treatment of low body weight and obsessive thinking in women with anorexia nervosa: a randomized, double-blind, placebo-controlled trial," American Journal of Psychiatry, vol. 165, no. 10, pp. 1281-1288, 2008.

[260] W. A. Banks, "Blood-brain barrier as a regulatory interface," Forum of Nutrition, vol. 63, pp. 102-110, 2010.

[261] K. G. Hofbauer, A.-C. Lecourt, and J.-C. Peter, "Antibodies as pharmacologic tools for studies on the regulation of energy balance," Nutrition, vol. 24, no. 9, pp. 791-797, 2008.

[262] L. A. W. Verhagen, E. Egecioglu, M. C. M. Luijendijk, J. J. G. Hillebrand, R. A. H. Adan, and S. L. Dickson, "Acute and chronic suppression of the central ghrelin signaling system reveals a role in food anticipatory activity," European Neuropsychopharmacology, vol. 21, no. 5, pp. 384-392, 2011.

[263] S. Cardona Cano, M. Merkestein, K. P. Skibicka, S. L. Dickson, and R. A. H. Adan, "Role of ghrelin in the pathophysiology of eating disorders: implications for pharmacotherapy," CNS Drugs, vol. 26, no. 4, pp. 281-296, 2012.

[264] B. Herpertz-Dahlmann, K. Holtkamp, and K. Konrad, "Eating disorders: anorexia and bulimia nervosa," Handbook of Clinical Neurology, vol. 106, pp. 447-462, 2012.

[265] P. J. Hay and A. M. Claudino, "Clinical psychopharmacology of eating disorders: a research update," International Journal of Neuropsychopharmacology, vol. 15, no. 2, pp. 209-222, 2012.

[266] T. Kishi, V. Kafantaris, S. Sunday, E. M. Sheridan, and C. U. Correll, "Are antipsychotics effective for the treatment of anorexia nervosa? Results from a systematic review and metaanalysis," Journal of Clinical Psychiatry, vol. 73, pp. e757-e766, 2012.

[267] F. D. Garcia, Q. Coquerel, J.-C. do Rego et al., "Antineuropeptide $\mathrm{Y}$ plasma immunoglobulins in relation to mood and appetite in depressive disorder," Psychoneuroendocrinology, vol. 73, no. 9, pp. 1457-1467, 2012.
[268] S. O. Fetissov and P. Déchelotte, "The new link between gutbrain axis and neuropsychiatric disorders," Current Opinion in Clinical Nutrition and Metabolic Care, vol. 14, no. 5, pp. 477-482, 2011. 


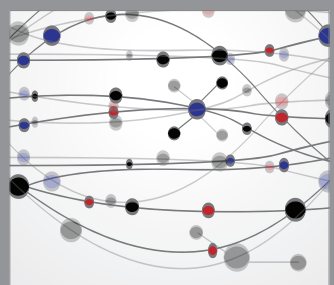

The Scientific World Journal
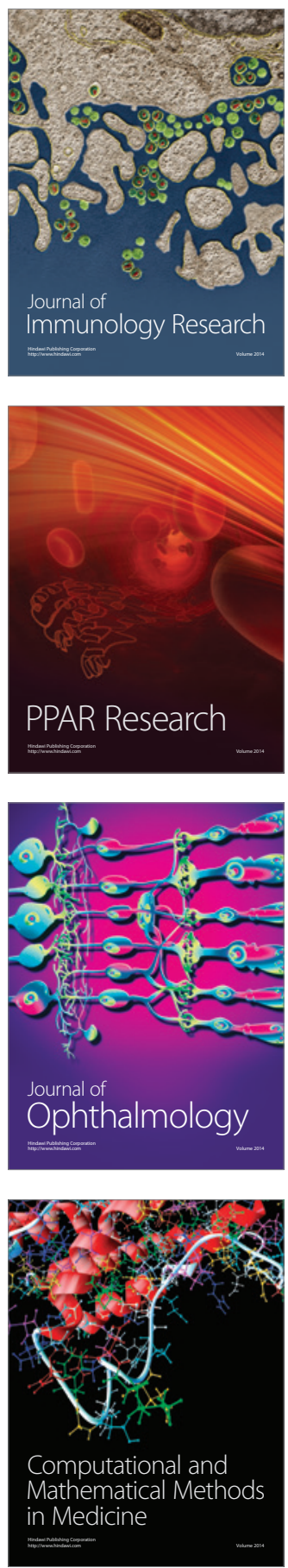

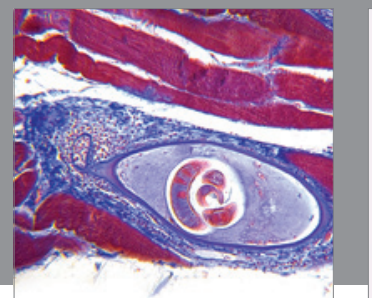

Gastroenterology

Research and Practice
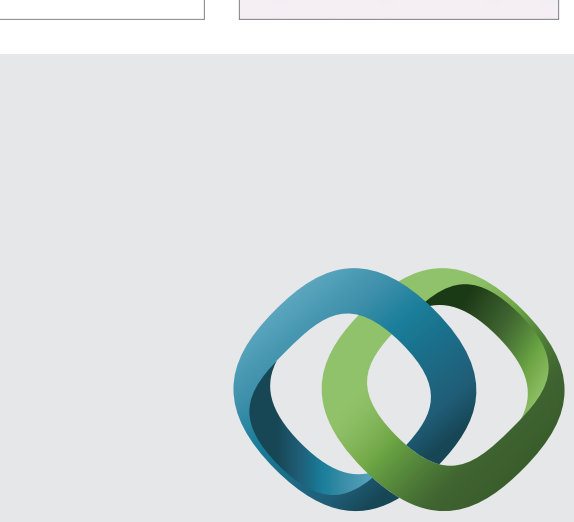

\section{Hindawi}

Submit your manuscripts at

http://www.hindawi.com
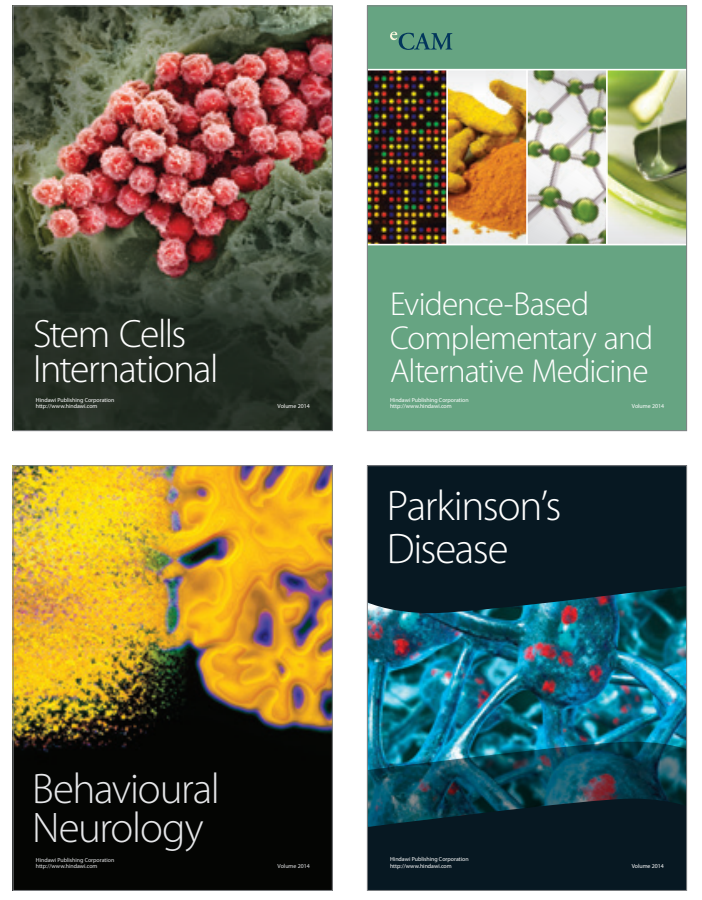
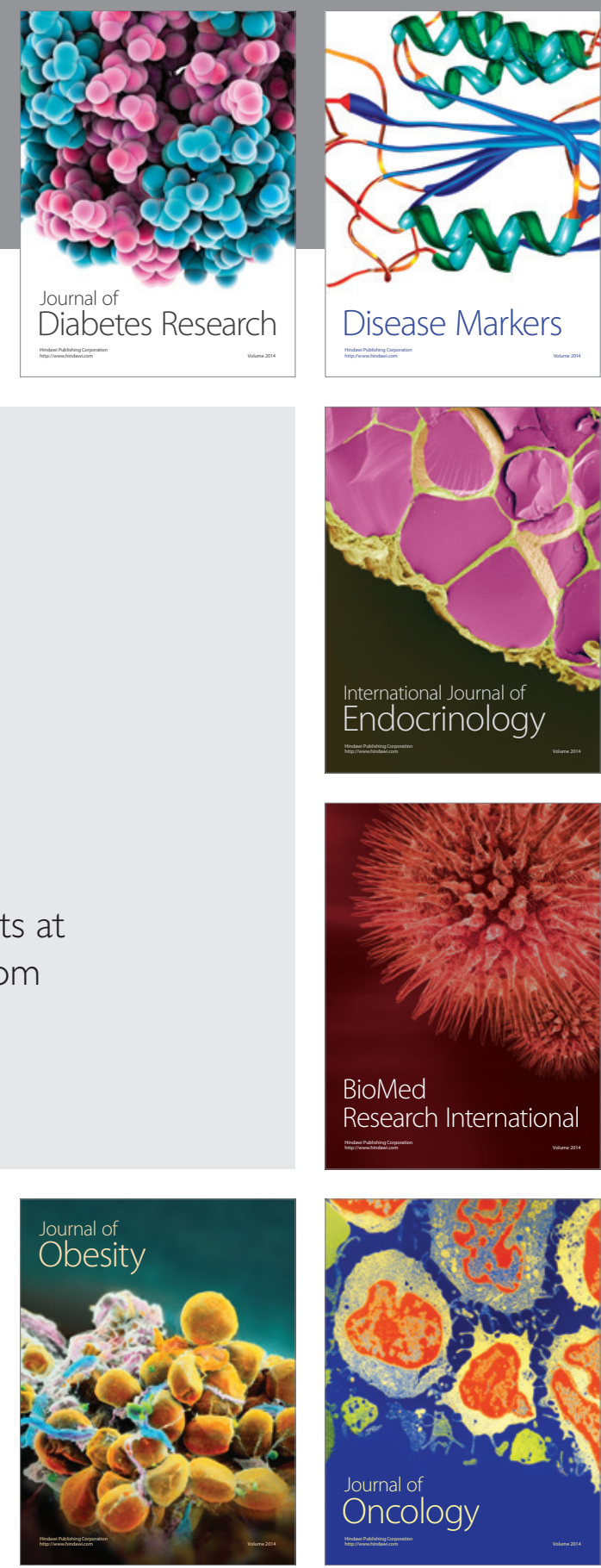

Disease Markers
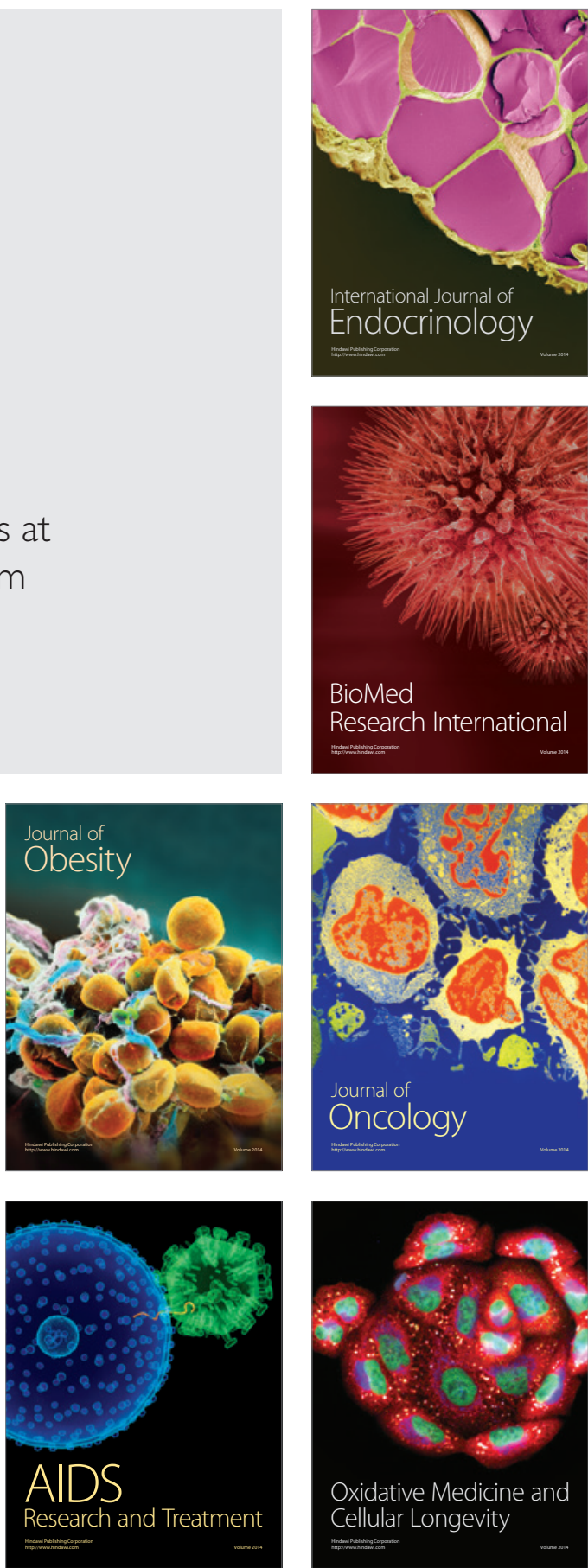